\title{
Post-Medieval Archaeology \\ Throwing Away Everything but the Kitchen Sink?: Large Assemblages, Depositional Practice and Post-Medieval Households in Cambridge \\ --Manuscript Draft--
}

\begin{tabular}{|c|c|}
\hline Manuscript Number: & PMA129R1 \\
\hline Full Title: & $\begin{array}{l}\text { Throwing Away Everything but the Kitchen Sink?: Large Assemblages, Depositional } \\
\text { Practice and Post-Medieval Households in Cambridge }\end{array}$ \\
\hline Article Type: & Unsolicited original research paper \\
\hline Keywords: & Deposition; Assemblages; Materialised temporality; Cambridge \\
\hline Corresponding Author: & $\begin{array}{l}\text { Craig Cessford, M.Litt } \\
\text { Cambridge Archaeological Unit, Department of Archaeology and Anthropology, } \\
\text { University of Cambridge } \\
\text { Cambridge, Cambridgeshire UNITED KINGDOM }\end{array}$ \\
\hline \multicolumn{2}{|l|}{$\begin{array}{l}\text { Corresponding Author Secondary } \\
\text { Information: }\end{array}$} \\
\hline Corresponding Author's Institution: & $\begin{array}{l}\text { Cambridge Archaeological Unit, Department of Archaeology and Anthropology, } \\
\text { University of Cambridge }\end{array}$ \\
\hline \multicolumn{2}{|l|}{$\begin{array}{l}\text { Corresponding Author's Secondary } \\
\text { Institution: }\end{array}$} \\
\hline First Author: & Craig Cessford, M.Litt \\
\hline \multicolumn{2}{|l|}{ First Author Secondary Information: } \\
\hline Order of Authors: & Craig Cessford, M.Litt \\
\hline \multicolumn{2}{|c|}{ Order of Authors Secondary Information: } \\
\hline Abstract: & $\begin{array}{l}\text { Developer-funded archaeologists investigating post- } 1750 \text { sites in Britain frequently } \\
\text { recover large assemblages of material, which appear to have been rapidly deposited in } \\
\text { features by particular households or other groups. Such assemblages possess } \\
\text { considerable interpretive potential, but this is yet to be fully exploited. This paper } \\
\text { proposes a nuanced approach to the analysis of such assemblages, one that is } \\
\text { critically aware of stratigraphic sequencing and historical deposition factors. }\end{array}$ \\
\hline Author Comments: & $\begin{array}{l}\text { Sorry to be so long in replying, I was a bit swamped by things and wanted to take a } \\
\text { good look at the comments. } \\
\text { The majority of the changes I have made relate to the reviewers and editors } \\
\text { comments. } \\
\text { I have also corrected a few mistakes and made some changes that effectively move } \\
\text { the paper further away from being a published conference paper to an independent } \\
\text { article. } \\
\text { As a result of various changes suggested by the referees the title of the article title } \\
\text { was no longer particularly appropriate. I have altered it to 'Throwing Away Everything } \\
\text { but the Kitchen Sink?: Large Assemblages, Depositional Practice and Post-Medieval } \\
\text { Households in Cambridge'. } \\
\text { I have decided to try and sidestep the nomenclature issue of 'clearance' groups etc. } \\
\text { somewhat, whilst I feel it is important I didn't want to get too fixated upon it and it would } \\
\text { have required substantial discussion. } \\
\text { I have added one figure (15), which was supposed to be in the earlier submission but } \\
\text { was inadvertently omitted. }\end{array}$ \\
\hline laing in & \\
\hline
\end{tabular}


Throwing away everything but the kitchen sink? Large assemblages, depositional practice and post-medieval households in Cambridge

By CRAIG CESSFORD

Institutional affiliation: Cambridge Archaeological Unit, University of Cambridge Abbreviated title: EVERYTHING BUT THE KITCHEN SINK?

Word count: $c .12,500$ (including references etc.)

Date submitted: December 2015, re-submitted March 2016, revised July 2016

Correspondence: Craig Cessford, Cambridge Archaeological Unit, Department of Archaeology and Anthropology, University of Cambridge, Downing Street, Cambridge, CB2 3DZ, UK

Email: cc250@cam.ac.uk 


\title{
Throwing away everything but the kitchen sink? Large assemblages, depositional practice and post-medieval households in Cambridge
}

\author{
By CRAIG CESSFORD
}

SUMMARY: Developer-funded archaeologists investigating post-1750 sites in Britain frequently recover large assemblages of material, which appear to have been rapidly deposited in features by particular households or other groups. Such assemblages possess considerable interpretive potential, but this is yet to be fully exploited. This paper proposes a nuanced approach to the analysis of such assemblages, one that is critically aware of stratigraphic sequencing and historical deposition factors.

\section{INTRODUCTION}

A recurrent element of archaeological sites from 1750 onwards in Britain, and indeed globally, is the deposition of substantial assemblages of hundreds of artefacts in individual features. ${ }^{1}$ Such assemblages are often referred to as 'clearance' groups, although a variety of other terms such as 'feature groups' and 'associated finds groups' have also been used. ${ }^{2}$ The most widely used term 'clearance' is problematic, as it implicitly suggests that the assemblages represent a totality of all the material possessions although a distinction between material 'discarded wholesale at one time' and 'unwanted, damaged or old fashioned household equipment ... thrown out en masse' has been noted. ${ }^{3}$ None of the proposed terms are particularly helpful and the application of such labels can be counterproductive, as they tend to mask differences. As a result such labels will be avoided as far as possible in this article and the simple term assemblage, denoting a group of artefacts found in close contextual association, will be used as far as possible. Whilst various definitions have been 
formulated one of the clearest and most quoted is that advanced by Pearce, who defines 'clearance' groups as:

...closed groups of deliberately discarded everyday household artefacts, with little evidence for chronological contamination, representing the final fill of a substantial cut feature, such as a cesspit, well or cistern, in which the contents are preserved as a discrete assemblage. ${ }^{4}$

Pearce identified five 'distinctive features' of such clearance groups: large quantities of pottery, a high proportion of large sherds from near complete vessels, a narrow date range for the material, minimal 'chronological contamination' and lower fragmentation and abrasion than other deposits. ${ }^{5}$ A rather more inclusive definition of such assemblages would be 'a closed deposit of material in a single feature, or group of related features, containing a significant quantity of material that is large enough to be atypical for the archaeological period locally and appears to be rapidly deposited'. This definition is subjective as it involves the determination of what is significant and atypical; this is however preferable to a more objective quantified definition, as this would tend to be arbitrary and insensitive to local circumstances.

Whilst large assemblages rightly attract considerable archaeological attention, there are a number of underlying issues with much of this treatment. In a developer-funded British context the four most significant are the relative unimportance — at least traditionally — ascribed to material of this period compared to earlier periods, the relative dis-empowerment of finds analysts, the implicit although by no means universal assumption that post-medieval deposition practice is unproblematic and the relative isolation of the study of the period from the rest of British archaeology. Unlike some of the areas globally where the archaeology of post-1750 urban centres has attracted most attention, notably North America and Australia, 
most post-medieval British urban sites have considerable phases of earlier urban occupation. Traditionally the latest deposits in such sequences have been viewed as the least significant and scant attention has been paid to them. ${ }^{6}$ Whilst the situation has improved, it nonetheless remains an unavoidable reality that when time and resources are limited, and the nature of earlier phases of activity is at best imperfectly understood, there will always remain considerable pressure to deal with later phases as rapidly as possible. British developerfunded archaeology exists in a system that effectively leads to the 'tyranny of the field archaeologist' and the relative disempowerment of finds analysts. ${ }^{7}$ This influences many publications that deal with large post-1750 assemblages. The most common form of publication is the detailed treatment of material from a single large assemblage deemed to be significant in some respect. Such publications are often driven principally by the interest of a single specialist; whilst typically involving highly rigorous and often theoretically informed analysis, lack of resources and the limitations of the skill-sets of the individual often lead to them becoming overly focussed upon particular material groups to the detriment of more holistic analysis. The rest of the site is usually largely ignored and certain classes of material that the specialist is not equipped to study themselves are either omitted entirely, or dealt with in a relatively cursory manner.

The other major form of publication is where large individual assemblages are presented as elements of larger sites. Such publications are typically dominated by field archaeologists; this means that whilst individual specialists discuss particular large assemblages they deem significant this usually occurs in isolation. Other specialists often do not discuss the same assemblages, principally because they are not particularly significant from their perspective, and field archaeologists rarely have the scope to integrate the various types of evidence. As a result it is either extremely time-consuming, or in some cases impossible, to reconstruct entire depositional assemblages from such publications. 
Much analysis of these large assemblages is rooted in the concept of the post-1750 period as part of a 'familiar past', where empirical common sense interpretations can be uncritically applied. ${ }^{8}$ This means that much of what passes for interpretation fails to rise above the level of 'pourquoi stories', or fictional tales to explain origins. A combination of wider academic disciplinary structures has meant that most discussion of post-1750 large assemblages has tended to be orientated to a spatial rather than a temporal canvas. It is common for British work to be firmly located within a global 'Historical Archaeology' framework of the post-1500 period, which in practice means one founded, defined and to a large degree dominated by North America. In contrast it is much less common for it to be firmly situated within the local longue durée, arguably stretching back over millennia.

This article has been inspired by the challenges of excavating, analysing and publishing a number of large post-1750 assemblages recovered by the Cambridge Archaeological Unit since 2005 and will be illustrated with regard to these. These principally relate to the Grand Arcade site in Cambridge, which produced over 35 distinctive assemblages of $c .1760-1940$ (Figs $1-2$, Table 1). ${ }^{9}$ These excavations covered 1.5 ha in a suburb of the town where occupation began in the 11th century and included significant portions of fourteen tenement plots from a single street block. By the 18th century the area was effectively part of the town core, albeit located close to the urban fringe until the beginning of the 19th century, when the inclosure of the surrounding open fields led to rapid expansion. The evidence from more limited excavations elsewhere in Cambridge indicates that there is considerable variation in the nature of assemblages between different parts of the town. Variation between British towns is also likely to have been significant, whilst a review of this falls beyond the scope of this article significant numbers of large assemblages have been published from parts of other towns including London, Oxford and Portsmouth. ${ }^{10}$ Additionally although most published assemblages are from urban centres they are also found 
in rural contexts and a comparison between urban and rural groups might well be revealing. ${ }^{11}$ Even further beyond the possibility of coverage in a single article is the global context. However it should be noted that broadly comparable assemblages are found elsewhere in Europe, are well known from North America and Australia and also occur in other areas of the world such as South America. ${ }^{12}$ The classic North American study of a number of assemblages from an area is the work in Oakland, whilst more recently work by Mary Beaudry has established new standards of integration and there are the beginnings of attempts at global comparisons between different countries. ${ }^{13}$

Having identified current limitations, the issue then arises how this situation can be improved upon. Whilst there are numerous possible avenues, due to limitations of space this paper will focus upon six areas:

- Issues of recovery and quantification, particularly how 'items' are defined

- Placing post-1750 material within a longue durée perspective

- Paying more attention to the features within which assemblages are found

- Contextualing larger assemblages within a continuum of depositional practice

- Paying more attention to the materialised temporality of assemblages

- Emphasising the need to separate the decision making and depositional processes of assemblages.

\section{RECOVERY AND QUANTIFICATION}

Methodological issues relating to the recovery, quantification and analysis of material are crucial to any comparative approach to large assemblages. Given the exigencies of British developer-funded archaeology the vast majority of large assemblages have been recovered in less than ideal circumstances. Such assemblages can still be analytically valuable, and given the inherent improbability that recovery standards will be significantly improved in the 
majority of instances, it is important to develop clear methodologies to cope with this reality. It is crucial that any limitations concerning features groups are explicitly identified. Major considerations include:

- Was recovery so rushed that a significant quantity of material is likely to have been missed?

- Is a proportion of the assemblage likely to be missing because of later truncation?

- Was the entire assemblage excavated, or was part left in situ due to logistical constraints?

- Was all material systematically recovered, or were certain categories of artefact not collected?

- Was any portion of the deposit sieved?

- How probable is contamination by extraneous material from adjacent deposits?

- Could individual depositional contexts be identified and the material from them separated?

- What were the preservational conditions, particularly did animal bone survive and was the deposit waterlogged?

An explicit statement regarding these factors allows an assessment of any likely limitations and factors affecting the assemblage.

Whilst there are many means of quantifying individual material types such as pottery, ${ }^{14}$ when considering assemblages composed of multiple material types Minimum Number of Items (MNI) have the greatest analytical potential, although other forms of quantification can play a supporting role. Although MNIs can theoretically be complex, especially if a high degree of statistical rigour is demanded, and there is a degree of methodological variation, their general application is relatively straightforward, albeit time- 
consuming, for most of the principal types of material, such as ceramics, glass and clay pipes. ${ }^{15}$ For ceramics the assemblage is divided by fabric, then subsequently by decoration, form and vessel size. Ideally at this stage all physically re-fitting sherds should be identified. The minimum number of vessels in each of these resultant smaller groups can then be calculated using a combination of several strategies depending on form, including the number of specific elements present such as handles or spouts and the total percentage of rim circumference present for circular vessels. In practice this is not an entirely objective exercise, with different practitioners employing slightly different methodologies, and as a result different MNI counts are not entirely comparable. Whilst this is a serious issue, it is unlikely to have a large enough impact to invalidate inter-assemblage comparisons, although the creation of generally accepted guidelines and methodologies would be advantageous. The techniques involved with glass vessels are similar, although re-fitting is usually less practical given the different nature of glass fragmentation. For tobacco pipes MNI counts are typically based on the number of bowls, heels plus spurs or mouthpieces present. Animal bone is more problematic and is discussed later, whilst metalwork, worked bone, worked stone etc. are usually distinctive enough and occur in such relatively small quantities that ad hoc systems usually suffice, although heavily corroded ironwork can represent an intractable issue. Leather items are also problematic when they occur in large numbers, especially when highly fragmented. In general shoes dominate and individual components such as soles may be made up of several parts. Although not entirely rigorous, in the sense that fuller analysis might identify additional items, one solution is to identify a single distinctive and relatively common element, such as the toe end, and base the MNI count upon that. ${ }^{16}$

One often relatively neglected category is building materials, which frequently occur in extremely large quantities rendering retention impractical. One realistic compromise involves rapid site-based quantification, where building materials are separated into broad 
form and fabric types and then quantified by counting the number of corners present and dividing the number of corners on an item (i.e. typically divide by eight). Quantifying building materials is particularly important as the deposition of large assemblages, particularly in redundant features, often appear to be contemporaneous with the demolition or re-modelling of nearby structures. If, as seems likely in many instances, the building demolition/re-modelling and assemblage deposition are — in some sense — related events constituting elements of a broader transition, then the building material component possesses considerable interpretative potential.

One fundamental issue relates to what constitutes an 'item'. MNI values are essentially calculated from the perspective of the contemporary analyst, which is not necessarily the same as how 'items' were conceived of in the past. One obvious example are objects which have two physically discrete components, such as a teapot and its lid. It could be argued that a teapot and lid should be quantified as a single MNI 'item'. Analysis at Grand Arcade indicates that there is a low correlation between the discard of teapots and lids, as they were discarded together in less than $20 \%$ of instances (Fig. 3). It appears that when one element was damaged - typically the teapot — the other was often retained for potential future re-use. Then at some later point the surviving element was discarded. A similar phenomenon can be observed with teacups/bowls and saucers, although these are rather less intimately functionally connected it appears that teacups/bowls were more susceptible to damage and that saucers may have been retained for future use. ${ }^{17}$ There are, however, some large assemblages from the Grand Arcade site and elsewhere in Cambridge where teacups and saucers were discarded together, in many instances apparently when only one was damaged.

Whilst some items recovered from large assemblages are complete, many vessels are only near- or semi-complete. It has been suggested that this may represent the discard of 
broken vessels that had previously been saved for repair or piled in middens. ${ }^{18}$ There are, however, practical issues with such interpretations, especially as it cannot be proved in instances where the recovery of an assemblage was incomplete. Additionally there are also other scenarios where parts of an item might be missing, for example there are indications from some Cambridge assemblages in the form of distinctive breakage patterns that larger ceramic items were deliberately broken to make it easier to transport them to their place of deposition. There is also evidence that several large assemblages at Grand Arcade and elsewhere were deposited in more than one feature, either because the volume of material was too large for any individual feature or through a desire to spread the material between features. If these two factors combine, then the presence of near- or semi-complete vessels would be unremarkable. Despite these provisos there are instances where near- or semicomplete vessels do genuinely appear to represent the deliberate deposition of incomplete items rather than other factors.

Whilst large assemblages are often excavated in the field or analysed as single entities, in some cases items may derive from several different stratigraphic entities within a feature. It is important that these are treated separately, at least until it can be determined if the various contexts are meaningfully different. ${ }^{19}$ In some instances where different stratigraphic entities simply represent minor distinctions within a rapid sequence of events it is probably best to amalgamate the material into a single assemblage. In others where there is more of a delay, particularly where some deposits accumulated whilst a feature was in use and other relate to its post-abandonment backfilling, it is crucial that material is considered separately.

It is also important to consider site formation processes and secondary deposition. ${ }^{20}$ There is compelling taphonomic evidence that over a quarter of assemblages from Cambridge contain material derived from middens or garden soil deposits. Whilst this is usually a 
relatively minor component, there are instances where it appears to constitute over a quarter of the deposited material. ${ }^{21}$ In several instances midden or garden soil material was apparently added deliberately, to ensure that the fill of a redundant feature could be well compacted and provide a stable foundation. In other cases there may have been a desire to remove a midden from a property. Fragments of objects from such sources do not properly constitute 'items' when they were re-deposited in the past, as they were primarily components of the midden or garden soil matrix rather than existing independently of it.

It is important to critique what exactly constitutes an 'item', not just because this has an impact upon quantification but also because it focuses attention upon the nature of discard and deposition in the past. Variability between assemblages means that it is nonsensical to attempt to create absolute rules concerning this issue, instead it is preferable to quantify all material present, and if appropriate subsequently produce a secondary more subjective reduced count with selected material excluded if it is believed that these do not truly represent 'items'.

\section{THE LONGUE DURÉE}

Whilst archaeologists should 'Think Globally, Dig Locally, ${ }^{22}$ it can be argued that digging locally must involve paying attention to the temporal longue durée or long-term slowly evolving historical structures of a particular place. ${ }^{23}$ Two factors need to be considered with regard to any longue durée approach; the first is that the quantities and nature of the material culture that individuals and groups possessed — their material wealth — changed markedly between periods. Depositional events analogous to large post-1750 assemblages may therefore have occurred in certain periods, but fail to achieve an archaeological recognition threshold. The other is that the types and prevalence of cut features material might be deposited into also changed markedly between periods. 
In Britain the longue durée of large assemblages arguably extends back as far as the Neolithic. ${ }^{24}$ There are, however, significant differences in depositional practice and it is only in the Romano-British period that closely analogous assemblages can be unambiguously identified. Examples include a quarry pit from Bishopsgate in London, Well 4 from Mucking and wells from Langdale Hale and Camp Ground in Cambridgeshire; although less exceptional groups occur more frequently. ${ }^{25}$ Unfortunately such assemblages have attracted relatively little general attention in Romano-British studies, indeed many of the weaknesses outlined for the post-1750 period are replicated in the Romano-British period. In the Early Anglo-Saxon period the character of deposition changes, and the pattern is much more analogous to the Prehistoric situation. It is only in the 11th to 12 th centuries that assemblages again become recognisable. The majority of these are quite small, in large part because levels of 'material wealth' — in particular pottery — were relatively low. Two early 12 th-century groups were recognised at the Grand Arcade site, but these contained only eight and four pottery vessels respectively (Fig. 4). The two groups were identified as distinctive due to the presence of reconstructable semi-complete vessels with a higher mean sherd weight than the rest of the assemblage and the recognition that the features were backfilled as part of a more general removal of some properties to make way for a planned urban development.

Instances of 13th- to 15th-century large assemblages are absent from Cambridge, discoveries elsewhere suggest that they probably existed but were relatively rare and have simply not yet been encountered. An early 13th-century pit from Worcester, which is believed to be linked to a house fire, consists of thirteen vessels. ${ }^{26}$ Although such groups are relatively infrequent in the archaeological record they are known from elsewhere and are often discussed as 'disaster groups', linked to unusual one off events. ${ }^{27}$ In the late 13 th century such groups become more frequent, in large part probably due to households possessing greater ceramic material wealth. Nigel Jeffries has explicitly extended the idea of 'clearance' 
groups to eleven late 13 th-century groups from London. ${ }^{28}$ These groups are distinguished by large quantities of well-preserved ceramics $-14-92$ vessels $($ mean $=53)-$ and their date of 1270/90-1300 suggests that they may be linked to changes in property ownership after the expulsion of the Jewish population in 1290. Perhaps the pre-eminent late 13th-century large assemblage is Pit 14 from Cuckoo Lane, Southampton, a large stone-lined cesspit with waterlogged fills sealed by building materials with signs of fire damage. ${ }^{29}$. At least 203 items are present — although this includes 118 organic items that would not normally survive including 49 pottery vessels. There is clear evidence that this is an unusual group, items that do not fill well with simple discard of unwanted material include a merchants seal matrix, which would have been a closely guarded object. There were also five dogs, a ferret, two sparrow-hawks and a Barbary ape and it is unlikely that such a number and range of pets would have died at around the same time under normal circumstances.

Such groups continue throughout the 14 th to 15 th centuries, and become much commoner in the 16th century. Although exact comparisons are difficult, at an impressionistic level it appears that such groups are perhaps ten times more common in the 16th century than in the late 13th to 15 th centuries. In Cambridge such groups are still relatively small, with 940 pottery vessels $($ mean $=21)($ Fig. 5$)$. This is much smaller than many of the late 13 th- to 15th-century groups from elsewhere, principally because publication has often understandably focussed upon the larger assemblages. There is also a reduction in some types of ceramic usage, with the widespread shift to metal cooking pots in the 15 th century. The other significant change in the 16th century is that glass vessels regularly appear in Cambridge assemblages, albeit in small numbers (mean $=$ two). Whilst the increasing number of assemblages in the 16th century appears to be partly linked to increasing levels of material wealth, it also reflects the fact that the number of redundant stone- and wood-lined features also increase markedly in Cambridge at this time, rising four- or five-fold. 
Assemblages continued to be deposited over the following centuries, with a series of changes that lead to them becoming larger. New types of material culture appear and there are changes in the materials that items are made from. Items that had previously been 'sturdy durables', which would often survive prolonged routine use, became 'semi-durables', which tend to break if used routinely. ${ }^{30}$ In Cambridge changes include the introduction of clay tobacco pipes $c .1580$ and their widespread usage from $c .1620-40$ onwards, the 'postmedieval ceramic revolution' where a wide range on new forms and fabrics were introduced c. 1600-50, glass vessels particularly bottles becoming commoner $c .1650-70$, the general usage of ceramic tableware particularly plates $c .1730-50$ and the widespread adoption of tea drinking and its associated material culture $c .1730-50$. Although similar changes occur in other urban centres the dates at which they took place often vary. Larger urban centres, particularly London, often apparently adopt new material earlier than smaller regional centres. There were also changes to the nature of features, particularly significant is that from the 17 th century onwards most, but by no means all, wells in Cambridge are backfilled with sterile material and do not contain large assemblages. In the early to mid 18th century Cambridge crossed the 'brick-threshold' so that this became the default choice for lining features,${ }^{31}$ making these much more readily archaeologically recognisable. Also in the early to mid 18th century the creation of horticultural planting beds becomes much commoner.

From a broad perspective large post-1750 assemblages need to be viewed not in chronological isolation, but as part of a much more long-term phenomenon. This is particularly apparent with regard to the late 13th century onwards, however whilst it might be tempting to view this as the origins of the phenomenon it is more likely that this relates more to an archaeological recognition threshold. 
The focus upon the material component deposited in large assemblages has diverted attention from the features that the items were deposited in. In Cambridge large assemblages can be divided into four principal depositional categories:

- The backfilling of redundant features; primarily cellars, cesspits, soakaways and robber cuts, plus more rarely wells and planting beds/holes

- Material added to the lower portions of functioning features, including cesspits, soakaways and planting beds/holes, as 'percolation fills' to improve drainage ${ }^{32}$

- Unlined pits, apparently dug solely to dispose of assemblages

- Spread horizontally as hardcore in foundations

The first thing to note is that, as has been recognised in London, ${ }^{33}$ in most instances features that could potentially contain large assemblages did not. This indicates that there was nothing axiomatic about such actions, but that they represent specific decisions which did not occur in the majority of instances (Fig. 6, Table 2). It should also be noted that different feature types generally contained different types of assemblage. The backfilling of redundant features (Figs 7-8) generally represent classic 'clearance' groups, with large quantities of ceramics plus glassware, tobacco pipes, animal bone and other material. Percolation fills are broadly similar in composition to backfilling groups, although they generally contain fewer items (Figs 911). Purpose dug pits apparently created solely for the disposal of material typically contained relatively small groups of $<50$ items and were often relatively atypical in other respects, frequently being dominated by a single type of material. Hardcore deposits are composed almost entirely of either pottery or glass deliberately broken into small fragments (Fig. 12). 
Whilst it is understandable that large assemblages have attracted the majority of attention, considering them in isolation is misleading. They are not the only way that material was disposed of and analysis suggests that they do not form a discrete category. They instead represent one extreme of a continuum of on-site urban depositional practice. At a simplistic level this continuum can be broken down into five distinguishable categories, although there are no absolute boundaries between groups and the categories represent a heuristic device:

- Classic 'clearance groups': large closed assemblages of artefacts discarded as a single deposit, typically consisting of several hundred items

- Smaller groups: small closed assemblages of artefacts discarded as a single deposit, typically consisting of dozens of items

- Large single items: disposal of individual large items

- Small single items: disposal of individual small items

- Fragments: small fragments of material, which appear to simply represent background or ambient levels present in most deposits at a site

Many of the larger assemblages, with combined totals of several hundred ceramics, glass vessels and tobacco pipes, relate to businesses, such as inns/taverns, whereas smaller groups where such items number in the dozens often appear to be linked to domestic households. As such it can be argued that they are fundamentally similar discard phenomena and it is the nature of the originating group that varies. The situation is further complicated by the fact that most business related assemblages probably contain a domestic element and vice versa (Fig. 9). There is a different prevalence of various types of material in at least some of the different types of deposit. This is best exemplified by instances where several categories of deposit can be linked to a single household. ${ }^{34}$ This occurred in a garden associated with a school at the Grand Arcade site that operated c. 1820-66 (Fig. 13, Table 3). There was a 
single large assemblage associated with the school (Planting Hole 3), plus three smaller groups (Planting Bed 17, Planting Hole $1 \&$ posthole F.6378). Additionally two one-squaremetre test pits were dug through the garden soil, recovering material that was present in this general layer as opposed to discrete features. Despite the large assemblage containing the majority of the material (73\%) unlike the smaller assemblages and garden soil it contained no bone toothbrushes or slate pencils. This pattern is replicated more generally and it appears to be linked principally to items that rapidly wore out through regular usage. In the case of toothbrushes the bristles wear out after only a few months and the bone handle is then discarded, whilst slate pencils wear down to the stage where the remaining stubs were too short to use in a similar period. The items were therefore effectively consumables, which were rapidly rendered useless and casually discarded. Another factor in this phenomenon is that these items were physically relatively small and tend to lack sharp edges that could prove dangerous. They were therefore disposed of in a relatively simple ad hoc manner. Taken in isolation either the large assemblage or the smaller groups present only partial perspectives upon the material culture utilised at the school. A consideration that includes both types is undoubtedly still incomplete, but nonetheless represents an improvement.

\section{MATERIALISED TEMPORALITIES}

Although the majority of large assemblages were deposited over a short period — of hours or perhaps days — the material they contain was acquired over years or more frequently decades, with a recognisable 'time lag' between production and deposition. ${ }^{35}$ Assemblages represent an archaeologically 'materialised temporality' ${ }^{36}$ or 'temporal palimpsest', where items of different ages and life spans are the constituents of a single depositional episode. Individual items possess a form of 'object biography', ${ }^{37}$ although these are important it can be argued that the overall assemblage biography is at least potentially greater than the sum of 
its constituent parts. The recognition of this introduces two significant caveats into the discussion of assemblages. The first is that the nature and composition of the households or other groups that generated assemblages would usually have changed markedly over the period that the material was being acquired and used (Fig. 14). During this period the economic fortunes of the household may have improved, declined or oscillated. Members of the household would have grown older and may also have been born, died or moved away. Concurrently the status of items of material culture could also change rapidly, for example newly developed ceramic fabrics or forms could move from being the height of fashion to everyday items over relatively short periods. Several Cambridge assemblages contain creamware where the earliest vessels were produced by Wedgwood in the 1770s, whilst later vessels were produced by other manufacturers in the 1780s (Fig. 15). The earlier elements in the service represent the height of fashion; creamware was refined by Wedgwood in $c .1762$ and was famously supplied to Queen Charlotte in 1765. Following the introduction of pearlware in $c .1775$ creamware became much comm and less socially exclusive and by 1778 it was 'no longer the choice thing it used to be, since every shop, house, and cottage is full of it' ${ }^{38}$ Although often almost undistinguishable, creamware vessels of the 1770s and 1780s in a single assemblage may represent radically different socio-economic entities. These two factors mean that any attempt to relate the material from an assemblage to the composition or socio-economic nature of the household that generated it must recognise that it represents a materialised temporality spanning a considerable period. ${ }^{39}$

Whilst analysis should embrace the concept of materialised temporality, attention should also be paid to types of material that are less affected by it. The most obvious are animal bones, which probably represent material that was consumed no more than a few weeks prior to deposition and although some large assemblages contain residual material, such as bones re-deposited from middens, this is usually readily identifiable by the condition 
of the bone. Additionally it is probable that groups of animal bone would be deposited in their entirety, with no selective retention of material unlike ceramics. Households also spent a much higher proportion of their disposable income on food, coal and other consumables than on ceramics and glassware, which were purchased much more infrequently, with tobacco pipes falling somewhere between these two groups, at least in terms of frequency of purchase. The only significant limitation would appear to be that after $c .1850$ animal bone becomes extremely rare as a component in archaeological assemblages, but is still occasionally present. ${ }^{40}$

Individual bones do not represent useful units of analysis. Whilst faunal analysts traditionally calculate the Minimum Number of Individuals this is often not a useful measure for the post-1750 period, as on many sites it is improbable that bones can be equated with the original presence of entire animals. Using meat weight calculations from 18th-early 20thcentury carcass weight data and the concept of the Minimum Number of Butchery Units (MNBU), relating to how animal carcasses were butchered and divided up, it is possible to estimate the amount of meat represented. ${ }^{41}$ Unfortunately, the MNBU — whilst useful for comparative purposes - substantially overestimates the actual amount of meat consumed. This is because the MNBU relates to wholesale units, whereas in 19th-20th century Western market economies meat was largely purchased by customers from professional butchers who sold it in Retail Units of Acquisition (RUA) that represent only c. $25 \%$ of the MNBU value. ${ }^{42}$ Such analysis — based on MNBU — is obviously problematic, but the relative proportions of different meat types clearly indicate a wide variation in consumption between households within the Grand Arcade street block in a 50 year period (Fig. 16, Table 4).

\section{FROM DECISION TO DEPOSITION}


Although a few assemblages from individual features can be interpreted in a relatively straightforward manner, notably those linked to the Great Fire of London in $1666,{ }^{43}$ the majority are more complicated and are the end result of a sequence of actions. The starting point of this process is generally the conscious decision to dispose of material, for whatever reason. The circumstances surrounding this decision will have a profound impact on the material that is ultimately deposited, but archaeologists can rarely — if ever — be certain what prompted a decision. Most suggestions are effectively best guesses, informed by a combination of the composition of the assemblage and documentary evidence. Proposed explanations for assemblage deposition include changes in the households occupying a property (with either the departing household disposing of unwanted material or the incomers discarding their predecessors leftovers), death of a female head of household with no one to inherit, disposal of unfashionable or damaged material and even the flight of a householder following an indictment for sodomy. ${ }^{44}$ In some instances the immediate stimulus to deposit material, which was already unwanted but in some form of 'storage', was the desire to use it to aid percolation in features such as cesspits or planting beds, to backfill redundant features or in response to the dictates of authorities such as municipal councils. ${ }^{45}$

Whatever the cause of the decision to dispose of material there would then be filtering processes, where items can be conceptualised as progressively losing status. ${ }^{46}$ Material that was still wanted by those responsible for the disposal process would be retained, some items for their usefulness whilst others maintained their status as 'household gods' ${ }^{47}$ Other material might be given as gifts to family members, neighbours, friends and servants. In this context it is notable that the types of artefact that arguably have the most intimate links to personal identity, such as items of adornment, shoes and clothing, ${ }^{48}$ are usually absent from large assemblages, indicating that they were typically retained and may have been deemed particularly appropriate as memento gifts. Rather less intimate — but still relatively personal 
— items are more frequently recovered, although identifying them is somewhat subjective. Their recognition is, however, important as they may well indicate that the deposition of material is linked to the death of an individual. One example is an assemblage linked to the death of Sarah Hopkins in 1843, containing several distinctive items such as a jug, a child's cup and a miniature watering can (Fig. 7). These items probably date to the period when Sarah was a young married woman (c. 1787-1800) and are likely to represent long treasured personal possessions, which were not significant enough to have been subsequently retained as memento gifts. A potentially rather more extreme example is a pet angora rabbit and a linnet probably kept as a song bird (plus a glass bird-feeder), from a London assemblage of $c$. $1770 .{ }^{49}$ The presence of these animals mirrors some medieval 'disaster pits', such as the example from Cuckoo Lane already mentioned, potentially suggesting that after the death of their owner these animals either inadvertently starved to death or were deliberately killed. Such elements emphasise the importance of considering the emotional aspects of disposing of items associated with a deceased family member. ${ }^{50}$

Material that was not wanted, but still had reuse value, in some sense reverted to being solely a 'commodity', as it had been before it was initially purchased, and might be sold ${ }^{51}$ Other items still possessed some value as 'matter' or 'stuff' if they could be recycled, this ranges from intrinsically valuable materials such as pewter, ${ }^{52}$ to wooden items which could be burnt as fuel and a wide range of materials including bricks, textiles, animal bones, paper and metal that were of value to 'scavengers', 'bone grubbers' and 'rag gatherers' ${ }^{53}$ The remaining material then became 'waste matter' to be deposited. There might still, however, be filtering processes, as waste matter was conceptually divided into categories such as ashes, rubbish (inorganic refuse), garbage (food remains) and night soil (bodily waste), with prohibitions against mixing different types of waste or disposing of them in a location or type 
of feature deemed inappropriate. ${ }^{54}$ After the depositional process filtering might occur, particularly with the decay of organic materials.

Some of these factors link to discussions concerning depositional practice, which in British archaeology since the 1980s has focussed upon 'structured deposition' or the concept that patterning in the deposition of material culture can indicate behavioural regularities. Originally applied to Neolithic material and developed with regard to Iron Age deposits, the concept has been widely applied within British prehistory and to a limited degree in the Romano-British and Anglo-Saxon periods. ${ }^{55}$ Structured deposition has been critiqued and the concept is relatively vague, leading to a broad range of deposits being grouped together when they probably represent different phenomena. ${ }^{56}$ Additionally there has been an assumption that patterning necessarily equates to intentionality and a focus on atypical deposits, based on the assumption that these denote symbolic or ritual activity. More recently there has been an acceptance that depositional practice should be viewed as a continuum and that 'average practice' is as worthy of attention as 'odd deposits'. At the broadest level the concept of structured deposition is applicable to post-1750 material, although its application needs to be relatively nuanced and holistic to represent a substantive improvement upon empirical common sense.

\section{DISCUSSION}

Whilst post-1750 assemblages recovered during developer-funded archaeology in Britain possess considerable analytical potential this has yet to be fully exploited and issues concerning recovery and quantification are important pre-requisites to this. Placing large assemblages within a longue durée perspective emphasises that they are not a uniquely post1750 phenomenon, rather one that increased markedly in frequency and scale at that time. This means that they cannot be entirely explained or interpreted in terms of mid-18th-19th- 
century phenomena. Allowing for the proportions of properties surviving to be investigated, at Grand Arcade large assemblages occur once every c. 40-50 years per property. This periodicity means that they are not routine acts, in the sense of a regularly followed procedure that individuals would be familiar with, although they do represent an established or prescribed way of doing something. The discard and deposition of large assemblages is also unlikely to have been a purely mundane activity, particularly as they appear to be frequently linked to major emotionally charged and stressful household events such as death. By paying more attention to the types of feature that they occur in and to the wider continuum of depositional practice that they are part of, they can be more fully contextualised. Perhaps the most important aspect to better understating large assemblages is to critique and interrogate their temporality, both in terms of their inherent materialised temporality and the process from the decision to discard to the act of deposition.

\section{ACKNOWLEDGEMENTS}

This article is based upon a paper presented at the Society for Post-Medieval Archaeology conference Routine and Ritual in the Post-Medieval Home, held at the University of York in September 2012. It incorporates the work of numerous field and post-excavation staff at the Cambridge Archaeological Unit on several projects since 2005. The work at Grand Arcade was jointly funded by Grosvenor Developments Ltd and the Universities Superannuation Scheme, as the Grand Arcade Partnership. The Cambridge Archaeological Unit part-funded my expenses to attend the conference and in particular I would like to thank my project manager Alison Dickens for her support and Richard Newman for his insights and help. The paper has benefited greatly from the graphical skills of Vicki Herring and the photography of Dave Webb, the animal bone photographs are courtesy of Lorrain Higbee. I would like to 
thank Alasdair Brooks for numerous pieces of guidance over the years, Philip Carstairs for access to his unpublished thesis and the two reviewers of the paper.

\section{BIBLIOGRAPHY}

Adams, W.H. 2003, 'Dating historical sites: the importance of understanding time lag in the acquisition, curation, use, and disposal of artifacts', Hist. Archaeol. 37, 38-64.

Bailey, G. 2007, 'Time perspectives, palimpsests and the archaeology of time', J. Anthropol. Archaeol. 26, 198-223.

Bartels, M.H. 2005, 'The Van Lidth de Jeude Family and the waste from their privy: material culture of a wealthy family in 18th-century Tiel, the Netherlands', Northeast Hist. Archaeol. 34, 15-60.

Bartels, M.H. \& van der Hoeven, L.M. 2005, 'Business from the cesspit: investigations into the socio-economic network of the Van Lidth de Jeude family (1701-78) in Tiel, the Netherlands, on the basis of shellac letter-seals from a cesspit', Post-Medieval Archaeol. 39, 155-71.

Beaudry, M. 2010, 'Privy to the feast: eighty to supper tonight', in Symonds 2010, 62-79.

Beaudry, M. 2013, 'Feasting on broken glass: making a meal of seeds, bones, and sherds', Northeast Hist. Archaeol. 42, 184-200.

Beck, M.E. \& Hill, M.E. 2004, 'Rubbish, relatives, and residence: the family use of middens', J. of Archaeol. Method \& Theory 11, 297-333.

Berg, M. \& Eger, E. (eds) 2002, Luxury in the Eighteenth Century, Basingstoke: Palgrave. Blinkhorn, P.W. \& Cumberpatch, C.G. 1998, 'The interpretation of artefacts and the tyranny of the field archaeologist', Assemblage 4, http://www.assemblage.group.shef.ac.uk/4/ [accessed 10 December 2013]. 
Boothroyd, N. \& Higgins, D. 2005, 'An inn-clearance group, c. 1800, from the Royal Oak, Eccleshall, Staffordshire', Post-Medieval Archaeol. 39, 197-203.

Bradley, C. 2000, 'Smoking pipes for the archaeologist', in Karklins 2000, 104-33.

Bradley, R. \& Gardiner, J. (eds), 1984, Neolithic Studies: A Review of Some Current Research, Oxford: Brit. Archaeol. Rep. Brit. Ser. 133.

Braudel, F. 1958, 'Histoire et sciences sociales: la longue durée', Annales. Histoire, Sciences Sociales 13, 725-53.

Brooks, A. 2005, An Archaeological Guide to British Ceramics in Australia, 1788-1901, Sydney: Australasian Society for Historical Archaeology \& Melbourne: La Trobe University Archaeology Programme.

Brooks. A. (ed.) 2015, The Importance of British Material Culture to Historical Archaeologies of the Nineteenth Century, Lincoln: University of Nebraska Press.

Brooks, A. \& Rodríguez Y., A.C. 2012, ‘A Venezuelan household clearance assemblage of 19th-century British ceramics in international perspective', Post-Medieval Archaeol. 46, 70-88.

Buteux, V. \& Jackson, R. 2000, 'Rethinking the "rubbish pit” in medieval Worcester', in Roskams 2000, 193-6.

Carstairs, M. 2013, 'The Secret Adventures of Crockery: an Archaeological Interpretation of Broken Ceramics and their Role in "Clearance" Deposits in the Post-Medieval Period', University of Leicester MA thesis.

Cessford, C. 2007, Grand Arcade, Cambridge: An Archaeological Excavation, Cambridge Archaeol. Unit Rep. 800.

Cessford, C. 2009, 'Post-1550 urban archaeology in a developer-funded context: an example from Grand Arcade, Cambridge', in Horning \& Palmer 2009, 301-21. 
Cessford, C. 2012, 'Life in a "cathedral of consumption": corporate and personal material culture recovered from a cellar at the Robert Sayle department store in Cambridge, England, ca. 1913-21', Int. J. Hist. Archaeol. 16, 784-808.

Cessford, C. 2013, 'Different times, different materials and different purposes: writing on objects at the Grand Arcade site in Cambridge', in Piquette \& Whitehouse 2013, 289317.

Cessford, C. 2014a, 'An assemblage of collegiate ceramics: mid-nineteenth century dining at Trinity Hall, Cambridge', Archaeol. J. 171, 340-80.

Cessford, C. 2014b, 'Assemblage biography and the life course: an archaeologically materialised temporality of Richard and Sarah Hopkins', Int. J. Hist. Archaeol. 18, 555-90.

Cessford, C. \& Dickens, A. 2013, 'Huntingdon Street, St. Neots: from medieval suburb to early 20th-century household', Proc. Cambridge Antiq. Soc. 102, 93-110.

Chadwick, A.M. 2012, 'Routine magic, mundane ritual: towards a unified notion of depositional practice', Oxford J. Archaeol. 31, 283-315.

Cohen, D. 2006, Household Gods: The British and their Possessions, New Haven: Yale University Press.

Cotter, J.L., Roberts, D.G. \& Parrington, M. 1992, The Buried Past: An Archaeological History of Philadelphia, Philadelphia: University of Pennsylvania Press.

Crane, B. 2000, 'Filth, garbage and rubbish: refuse disposal, sanitary reform and nineteenthcentury yard deposits in Washington D.C.', Hist. Archaeol. 34, 20-38.

Crook, P. 2011, 'Rethinking assemblage analysis: new approaches to the archaeology of working-class neighborhoods', Int. J. Hist. Archaeol. 15, 582-93.

Crook, P. 2015. “"Home”-made: exploring the quality of British domestic goods in nineteenth-century urban assemblages', in Brooks 2015, 305-34. 
Crook, P. \& Murray, T. 2004, 'The analysis of cesspit deposits from The Rocks, Sydney', Australasian Hist. Archaeol. 22, 44-56.

Dalwood H. \& Edwards, R. 2004, Excavations at Deansway, Worcester, 1988-9: RomanoBritish Small Town to Late Medieval City, Counc. Brit. Archaeol. Res. Rep. 139.

Davey, P.J. 1987, 'The post-medieval period', in Schofield \& Leech 2013, 69-80.

de Clercq, W. et al. 2007, 'Living in times of war: waste of $c .1600$ from two garderobe chutes in the castle of Middelburg-in-Flanders (Belgium)', Post-Medieval Archaeol. 41, 1-63.

Dickens, R.S. (ed.) 1982, Archaeology of Urban America: The Search for Pattern and Process, New York: Academic Press.

Evans, C., Appleby, G., Lucy, S. \& Regan, R. 2013, Romano-British Communities at Colne Fen, Earith: An Inland Port and Supply Farm, Cambridge Archaeol. Unit, Process and Hist. at Colne Fen, Earith 2.

Finer, A. \& Savage, G. 1965, The Selected Letters of Josiah Wedgwood, London: Cory, Adams \& Mackay.

Fontaine, L. 2002, 'The circulation of luxury goods in eighteenth-century Paris: social redistribution and an alternative currency', in Berg \& Eger 2002, 89-102.

Fox, R. \& Barton, K.J. 1986, 'Excavations at Oyster Street, Portsmouth, Hampshire, 196871', Post-Medieval Archaeol. 20, 31-255.

Fryer, K. \& Shelley, A. 1998, 'Excavation of a pit at 16 Tunsgate, Guildford, Surrey, 1991', Post-Medieval Archaeol. 31, 139-230.

Fulford, M. 2001, 'Links with the past: pervasive "ritual” behaviour in Roman Britain', Britannia 32, 199-218.

Garrow, D. 2007, 'Placing pits: landscape occupation and depositional practice during the Neolithic in East Anglia', Proc. Prehist. Soc. 73, 1-24 
Garrow, D. 2012, 'Odd deposits and average practice: a critical history of the concept of structured deposition', Archaeol. Dialogues 19, 85-115.

Garrow, D., Beadsmoore, E. \& Knight, M. 2005, 'Pit clusters and the temporality of occupation: an Earlier Neolithic site at Kilverstone, Thetford, Norfolk', Proc. Prehist. Soc. 71, 139-57.

Gilchrist, R. 2012, Medieval Life: Archaeology and the Life Course, Woodbridge: Boydell \& Brewer.

Gooder, E. 1984, 'The finds from the cellar of the Old Hall, Temple Balsall, Warwickshire', Post-Medieval Archaeol. 18, 149-249.

Hamerow, H., 2006, “'Special deposits” in Anglo-Saxon settlements', Medieval Archaeol. 50, $1-30$.

Hamling, T. \& Richardson, C. (eds) 2010, Everyday Things: Medieval and Early Modern Material Culture, Farnham: Ashgate.

Harward, C., Holder, N. \& Jeffries, N. 2015. The Spitalfields Suburb 1539-c. 1880: Excavations at Spitalfields Market, London E1, 1991-2007, MOLA Monogr. 61.

Hassall, T.G., Halpin, C.E. \& Mellor, M. 1985, 'Excavations in St. Ebbe’s, Oxford, 19671976: Part II, post-medieval domestic tenements and the post-Dissolution site of the Greyfriars', Oxoniensia 49, 153-275.

Heck, D.A. \& Balicki, J.F. 1998, 'Katherine Naylor's "House of Office”: a seventeenthcentury privy', Hist. Archaeol. 32, 24-37.

Hill, J.D. 1995, Ritual and Rubbish in the Iron Age of Wessex: A Study on the Formation of a Specific Archaeological Record, Brit. Archaeol. Rep. Brit. Ser. 242.

Hill, S.H. 1982, 'An examination of manufacture-deposition lag for glass bottles from late historic sites', in Dickens 1982, 291-328. 
Hingley, R. 2006, 'The deposition of iron objects in Britain during the later prehistoric and Roman periods: contextual analysis and the significance of iron', Britannia 37, 21357.

Hingley, R. \& Willis, S. (eds) 2007, Roman Finds: Context and Theory, Oxford: Oxbow.

Horning, A. \& Palmer, M. (eds) 2009, Crossing Paths or Sharing Tracks? Future Directions in the Archaeological Study of Post-1550 Britain and Ireland, Woodbridge: Boydell \& Brewer.

Huelsbeck, D.R. 1991, 'Faunal remains and consumer behaviour: what is being measured?', Hist. Archaeol. 25, 62-76.

Huggins, P.J. 1969, 'Excavations at Sewardstone Street, Waltham Abbey, Essex, 1966', PostMedieval Archaeol. 3, 47-99.

Hunter, R.R. \& Miller, G.L. 1994, 'English shell-edged earthenwares', Antiques March 1994, $432-43$.

Jeffries, N. 2006, 'The Metropolis Local Management Act and the archaeology of sanitary reform in the London Borough of Lambeth 1856-86', Post-Medieval Archaeol. 40, 272-90.

Jeffries, N. 2012, 'Late 13th-century household "clearance” groups on Gresham Street and the London jewry', London Archaeol. 13, 119-22.

Jeffries, N., Featherby, R. \& Wroe-Brown, R. 2014, "“Would I were in an alehouse in London!": a finds assemblage sealed by the Great Fire from Rood Lane, City of London', Post-Medieval Archaeol. 48, 261-84.

Jeffries, N. \& Watson, B. 2012, 'From Saxon Lundenwic to Victorian Rookery: excavations at the City Lit, Keeley Street, London WC2', Trans. Lond. Middx. Archaeol. Soc. 65, $85-7$. 
Joy, J. 2009, 'Reinvigorating object biography: reproducing the drama of object lives', World Archaeol. 41, 540-56.

Karklins, K. (ed.) 2000, Studies in Material Culture Research, Uniontown: Society for Historical Archaeology \& Parks Canada.

Lamdin-Whymark, H. \& Thomas, J. (eds) 2012, Regional Perspectives on Neolithic Pit Deposition: Beyond the Mundane, Neolithic Stud. Group Seminar Ser. 12.

Lemire, B. 1991, 'Peddling fashion: salesmen, pawnbrokers, taylors, thieves and the secondhand clothes trade in England, c. 1700-1800', Textile Hist. 22, 67-82.

Lucas, R. 1997, 'When did Norfolk cross “the brick threshold”?', Vernacular Architect. 28, $68-80$.

Lucy, S., Evans, C. \& Jeffries, R. forthcoming, Romano-British Settlement and Cemeteries at Mucking: Excavations by Margaret and Tom Jones, 1965-1978, Oxford: Oxbow.

Lyman, R.L. 1979, ‘Available meat from faunal remains: a consideration of techniques’, Am. Antiq. 44, 536-46.

Majewski, T. \& Gaimster, D.R.M. (eds) 2009, International Handbook of Historical Archaeology, New York: Springer.

Martin, A.S. 1989, 'The role of pewter as missing artefact: consumer attitudes toward tablewares in late 18th century Virginia', Hist. Archaeol. 23, 1-27

McCarthy, J. \& Ward, J. 2000, 'Sanitation practices, depositional processes and interpretive contexts of Minneapolis privies', Hist. Archaeol. 34, 111-29.

Morris, J. \& Jervis, B. 2011, 'What's so special? A re-interpretation of Anglo-Saxon "special deposits", Medieval Archaeol. 55, 66-81.

Newman, R. \& Wilkinson, P. 1997, 'Excavations at Llanmaes, near Llantwit Major, South Glamorgan', Post-Medieval Archaeol. 30, 187-233.

Orser, C.E. 1986, A Historical Archaeology of the Modern World, London: Plenum. 
Orton, C., Tyers, P. \& Vince, A. 1993, Pottery in Archaeology, Cambridge: University Press.

Pearce, J. 2000, 'A late 18th-century inn clearance assemblage from Uxbridge, Middlesex', Post-Medieval Archaeol. 34, 144-86.

Pearce, J. \& Taylor, R. 2013, 'The stock-in-trade of a Parish Scavenger: an 18th-century community reflected in refuse from excavations at 9 and 11 Duke Street, London', Post-Medieval Archaeol. 47, 281-322.

Pennell, S. 2010a, “For a crack and a flaw despis'd”: thinking about ceramic semi-durability and the "everyday" in early modern England', in Hamling \& Richardson 2010, 27-40.

Pennell, S. 2010b, “All but the kitchen sink': household sales and the circulation of secondhand goods in early modern England', in Stobart \& Van Damme 2010, 37-56.

Piquette, K.E. \& Whitehouse, R.D. (eds) 2013, Writing as Material Practice: Substance, Surface and Medium, London: Ubiquity Press.

Platt, C. \& Coleman-Smith, R. 1975, Excavations in Medieval Southampton, 1953-1969, London: Leicester University Press.

Pomfret, R. 2008, 'Attribution of the "IH" mark', Transferware Collectors Club Bull. 9.3, 45.

Poulain, M. 2013, 'Notes on the quantification of post-medieval pottery in the Low Countries', Post-Medieval Archaeol. 47, 106-18.

Praetzellis, M. \& Praetzellis, A. 2004. Putting the “There” There: Historical Archaeologies of West Oakland, Cypress Replacement Proj. Interp. Proj. Rep. 2.

Prosser, L. et al. 2012, 'Household archaeology, lifecycles and status in a nineteenth-century Australian coastal community', Int. J. Hist. Archaeol. 16, 809-27.

Richards, C. \& Thomas, J. 1984, 'Ritual activity and structured deposition in Later Neolithic Wessex', in Bradley \& Gardiner 1984, 189-218. 
Roskams, S. (ed.) 2000, Interpreting Stratigraphy: Papers Presented to the Interpreting Stratigraphy Conferences 1993-1997, Archaeol. Rep. Brit. Ser. 910.

Schiffer, M.B. 1983, 'Toward the identification of formation processes', Am. Antiq. 48, 675706.

Schiffer, M.B. 1987, Formation Processes of the Archaeological Record, Albuquerque: University of New Mexico Press.

Schofield, J. \& Leech, R. 1987. Urban Archaeology in Britain, Counc. Brit. Archaeol. Res. Rep. 61.

Stevens, S.C. \& Ordoñez, M.T. 2005, 'Fashionable and work shoes from a nineteenth-century Boston privy', Hist. Archaeol. 39, 9-25.

Stobart, J. \& Van Damme, I. (eds) 2010, Modernity and the Second-Hand Trade: European Consumption Cultures and Practices 1700-1900, Basingstoke: Palgrave MacMillan.

Symonds. J. (ed.) 2010, Table Settings: The Material Culture and Social Context of Dining in the Old and New Worlds AD 1700-1900, Oxford: Oxbow Books.

Tarlow, S. 2000, 'Emotion in archaeology', Curr. Anth. 41, 713-46.

Tarlow, S. 2012, 'The archaeology of emotion and affect', Annu. Rev. Anth. 41, 169-85.

Tarlow, S. \& West, S. (eds) 1999, The Familiar Past? Archaeologies of Later Historical Britain, London: Routledge.

Taylor, K. \& Hull, G. 2002, 'Excavation of post-medieval features and a dump of late eighteenth-century artefacts from 5/6-7 Market Street, Oxford', Oxoniensia 67, 31357.

Trotter, D. 2008, 'Household clearances in Victorian fiction', 19: Interdisciplinary Studies in the Long Nineteenth Century 6, http://www.19.bbk.ac.uk [accessed 10 December 2013]. 
Turner, M.E., Beckett, J.V. \& Afton, B. 2001, Farm Production in England 1700-1914, Oxford: University Press.

Turner, M., Beckett, J. \& Afton, B. 2003, Crop Yields and Animal Carcass Weights in England, c. 1700-1914, Colchester: UK Data Archive.

Tyers, I. 1980, 'An assemblage of Roman ceramics from London', London Archaeol. 4, 36774.

Vince, A.G. \& Egan, G. 1981, 'The contents of a late 18th-century pit at Crosswall, City of London', Trans. London Middlesex Archaeol. Soc. 32, 159-82.

Voss, B. L. \& Allen, R. 2010. 'Guide to ceramic MNV calculation qualitative and quantitative analysis', Techn. Briefs in Hist. Archaeol. 5, 1-9.

Wheeler, K. L. 2000, 'Theoretical and methodological considerations for excavating privies', Hist. Archaeol. 34, 3-19.

White, C.L. \& Beaudry, M. 2009, ‘Artifacts and personal identity', in Majewski \& Gaimster 2009, 209-25.

Willmott, H. 2002, Early Post-Medieval Vessel Glass in England c. 1500-1670, Council for British Archaeology Research Report 132.

Yamin, R. 1998, 'Lurid tales and homely stories of New York's notorious Five Points', Hist. Archaeol. 32, 74-85.

\section{ABBREVIATIONS}

MNI Minimum Number of Items

MNBU Minimum Number of Butchery Units

RUA Retail Units of Acquisition 
Cambridge Archaeological Unit, Department of Archaeology and Anthropology, University of Cambridge, Downing Street, Cambridge, CB2 3DZ, UK

$$
\text { [cc250@cam.ac.uk] }
$$

The sites will be archived with the Cambridgeshire County Council and can be viewed by prior arrangement; the site codes for Grand Arcade are GAD05 and GAD06.

\section{NOTES}

${ }^{1}$ Good British published examples of such assemblages include a cesspit from London backfilled with material from a household in c. 1770 (Vince \& Egan 1981), a pit from Guildford backfilled c. 1702-14 with material associated with the Tun Inn Fryer \& Shelley 1998) and a well from Uxbridge backfilled c. 1785-1800 with material from the King's Arms (Pearce 2000).

${ }^{2}$ The term clearance is used by Vince \& Egan 1981, 77 and Fryer \& Shelley 1998, 142, 147. It is more fully defined by Pearce 2000 and has subsequently been more widely adopted e.g. Boothroyd \& Higgins 2005, Brooks \& Rodríguez Y. 2012. For feature group see Cessford 2009, 307-09 and for 'associated finds group' see Carstairs 2013.

${ }^{3}$ Pearce 2000, 177.

${ }^{4}$ Pearce 2000, 144.

${ }^{5}$ Pearce 2000, 145.

${ }^{6}$ Davey 1987, 69-70.

${ }^{7}$ Blinkhorn \& Cumberpatch 1998.

${ }^{8}$ Tarlow \& West 1999.

${ }^{9}$ Cessford 2007. Where not otherwise stated all references to assemblages relate to the Grand Arcade site. 
${ }^{10}$ On London see Harward et al. 2015 and Jeffries \& Watson 2012, for Oxford Hassall et al. 1985 and for Portsmouth Fox \& Barton 1986.

${ }^{11}$ A good rural example from Britain is Gooder 1984.

${ }^{12}$ Examples from the Low Countries include Bartels 2005, Bartels \& van der Hoeven 2005 and de Clercq et al. 2007, classic examples from North America include Heck \& Balicki 1998, Wheeler 2000 and Yamin 1988, a good Australian study is Crook \& Murray 2004, whilst a South American example is Brooks \& Rodríguez Y. 2012.

${ }^{13}$ On Oakland see Praetzellis \& Praetzellis 2004, on integration Beaudry 2010 and 2013 and for international comparison between Sydney and London see Crook 2011 and 2015.

${ }^{14}$ Orton et al. 1993; Poulain 2013.

${ }^{15}$ Bradley 2000; Brooks 2005; Voss \& Allen 2010; Willmott 2002.

${ }^{16}$ Stevens \& Ordoñez 2005.

${ }^{17}$ Carstairs 2013.

${ }^{18}$ Carstairs 2013.

${ }^{19}$ On the importance of careful stratigraphic excavation see Heck \& Balicki 1998 and Wheeler 2000.

${ }^{20}$ The classic statements on site formation processes are Schiffer 1983 and Schiffer 1987.

${ }^{21}$ Taylor \& Hull 2002.

22 Orser 1986, 183.

${ }^{23}$ Braudel 1958.

${ }^{24}$ Garrow 2007; Garrow et al. 2005; Lamdin-Whymark \& Thomas 2012.

${ }^{25}$ Evans et al. 2013; Lucy et al. forthcoming; Tyers 1980.

${ }^{26}$ Dalwood \& Edwards 2004, 86-87, 147, 333-34.

${ }^{27}$ Buteux \& Jackson 2000.

${ }^{28}$ Jeffries 2012. 
${ }^{29}$ Platt \& Coleman-Smith 1975; see also Gilchrist 2012, 115-17.

${ }^{30}$ Pennell 2010a.

${ }^{31}$ Lucas 1997.

${ }^{32}$ Cotter et al. 1992, 161, 307-09, 450; see also Carstairs 2013.

${ }^{33}$ Harward et al. 2015, 260.

${ }^{34}$ Cessford 2009, 313-17.

${ }^{35}$ Adams 2003; Hill 1982.

${ }^{36}$ Cessford 2014a; Cessford 2014b.

37 Joy 2009.

${ }^{38}$ Finer \& Savage 1965, 220-21.

${ }^{39}$ For a good example of this see Prosser et al. 2012.

${ }^{40}$ Cessford and Dickens 2013, 104-07; Jeffries 2006, 286.

${ }^{41}$ Lyman 1979; Turner et al. 2001; Turner et al. 2003. Rough estimates of dressed meat weights have been used for other species: rabbit or hare $2.5 \mathrm{~kg}$, chicken or duck $2.0 \mathrm{~kg}$, goose $3.0 \mathrm{~kg}$, pigeon $0.5 \mathrm{~kg}$, turkey $2.5 \mathrm{~kg}$, grey partridge $0.2 \mathrm{~kg}$, red grouse $0.3 \mathrm{~kg}$, pheasant $1.5 \mathrm{~kg}$. These probably over-estimate the relative importance of these species compared to the main domesticates, but this does not invalidated inter-assemblage comparisons.

${ }^{42}$ Huelsbeck 1991, 69-70, table 2. For an example see Cessford 2013, 104-07.

${ }^{43}$ Jeffries et al. 2014.

${ }^{44}$ Boothroyd \& Higgins 2005, 197; Huggins 1969; Jeffries 2006, 280; Pearce 2000, 177-178; Wheeler 2000, 8, 11-12.

${ }^{45}$ Crook \& Murray 2004; Jeffries 2006; Pearce \& Taylor 2013.

${ }^{46}$ Trotter 2008.

${ }^{47}$ Cohen 2006.

${ }^{48}$ White \& Beaudry 2009. 
${ }^{49}$ Vince \& Egan 1981.

${ }^{50}$ Tarlow 2000; Tarlow 2012.

${ }^{51}$ Fontaine 2002; Lemire 1991; Pennell 2010b; Trotter 2008.

${ }^{52}$ Martin 1989.

${ }^{53}$ For an assemblage possibly linked to such and individual see Pearce \& Taylor 2013.

${ }^{54}$ Crane 2000; McCarthy \& Ward 2000.

${ }^{55}$ Fulford 2001; Hamerow 2006; Hill 1995; Hingley 2006; Morris \& Jervis 2011; Richards \& Thomas 1984.

${ }^{56}$ Chadwick 2012; Garrow 2012. 


\section{LIST OF FIGURE CAPTIONS}

FIG. 1

Grand Arcade, Cambridge: site location, contains Ordnance Survey data C crown copyright and database right 2012.

FIG. 2

Maps of large assemblages deposited at the Grand Arcade site, Cambridge, 1760-1940:

William Custance's map 1798 showing location of large assemblages of 1760-1800 (upper left) and 1800-50 (upper right) and Ordnance Survey map surveyed in 1885 showing locations of large assemblages of c. 1850-1900 (lower left) and 1900-40 (lower right).

FIG. 3

Ceramics from the Grand Arcade site, Cambridge, where there is ambiguity about what constitutes a deposited 'item'. Black basalt teapot lid and pearlware teapot deposited as backfilling in redundant feature Cellar 4 1843-45. The matching teapot and lid are missing and additionally both items are incomplete, despite being distinctive and easily recognisable. This indicates that teapots and their lids were in some circumstances separate items (photographs by Dave Webb \& Craig Cessford).

FIG. 4

Early 12th-century cesspit and pit at the Grand Arcade site in Cambridge which contained significant ceramic assemblages taphonomically comparable to later large assemblages, including two Thetford-type ware jars, a St. Neots-type ware jar and bowl shown. These represent the earliest known medieval assemblages from Cambridge that may be analogous to 
later assemblages. Although these groups consist of only eight and four ceramic vessels respectively this may well represent a significant proportion of the pottery that most households in Cambridge possessed at this time (drawings by Vicki Herring, photographs by Craig Cessford).

FIG. 5

Timber-lined feature at Hostel Yard, Corpus Christi College, Cambridge, backfilled in the mid-late 16th-century with selected items illustrated. The backfilling contained a range of complete or semi-complete ceramics, glassware and other items taphonomically comparable to later large assemblages (drawings by Vicki Herring, photographs by Dave Webb \& Craig Cessford).

FIG. 6

Different feature types at the Grand Arcade site in Cambridge, 1760-1940, showing the relative prevalence of different types of deposit in them (upper) and the changing prevalence of principal depositional categories as defined in the text over time (lower).

FIG. 7

Section and photograph of Cellar 4 at the Grand Arcade site, Cambridge, backfilled 1843-45, demonstrating the different quantities of 'items' in different deposits plus the degree of interconnectedness of the material from different stratigraphic deposits. There are also a jug, child's cup and watering can interpreted as late 18th-century personal items, their presence serves to underlie the connection of the deposition of this material to the death of Sarah Hopkins and the issue of the potential emotional involvement of those who discarded the material (drawing by Vicki Herring, photographs by Dave Webb \& Craig Cessford). 
FIG. 8

Soakaway 2 at the Grand Arcade site, Cambridge, with a selection of ceramics, the stratigraphic evidence indicates that these were deposited during backfilling 1813-23 and relate to the Headley family of grocers who had lived at the property since $c .1723$ (drawings by Vicki Herring, photographs by Dave Webb \& Craig Cessford).

FIG. 9

View of early 18th-mid 19th-century buildings at the Grand Arcade site, Cambridge, with red dots indicating location of large assemblages, plus view of Soakaways 3-4 which had percolation fills added in 1780-90 and 1808-25 respectively with selected material from Soakaway 3. The illustrated material relates to the household of Thomas Wicks, the cook at Emmanuel College 1807-51 and is a mixture of domestic and business related material (photographs by Dave Webb \& Craig Cessford).

FIG. 10

Planting Beds 7-8 at the Grand Arcade site, Cambridge, with a selection of recovered material. The lower ceramics related to dining etc. were added as a percolation fill 1770-90, whereas the upper flower pots and lead planting labels were deposited 1800-20 when the planting beds went out of use. This distinction demonstrates the importance of careful stratigraphic excavation and not necessarily amalgamating all material from a feature for analytical purposes (drawings by Vicki Herring, photographs by Craig Cessford).

FIG. 11 
Planting Bed 11 at the Grand Arcade site, Cambridge, with a selection of ceramics from the percolation fill of 1770-90. Possibly from the household of a widow named Mary Ward living at the property in 1772. Many of the items appear to have been complete or only slightly damaged prior to deposition, they were however all somewhat old-fashioned by 1780 and represent a range of fabrics and patterns so may have been replaced by a matching service (photographs by Dave Webb \& Craig Cessford).

FIG. 12

'H'-shaped structural Foundation 3 at the Grand Arcade site, Cambridge, with glass bottle fragments used as hardcore 1884-90. The fragments were overwhelmingly from torpedoshaped soda water bottles, which had been rendered obsolete by the adoption of the Codd form of soda water bottle. The firms represented are either not local or had ceased trading some time earlier, for example Samuel Ekin had left Cambridge in the 1850s, and may represent bottles that accumulated because they were unwanted or where it was not possible to return them to claim the deposit paid for them (drawings by Vicki Herring, photograph by Craig Cessford).

FIG. 13

Garden associated with school of 1820-66 at the Grand Arcade site, Cambridge: features plotted on Ordnance Survey map surveyed in 1885, relative proportions of material from different types of deposit, view of Planting Hole 3 with selected ceramics from its percolation fill of 1822-34 and slate pencils from other depositional contexts. Two matching tea cups and saucers from different services deposited in the percolation fill of Planting Hole 3, it appears that both saucers were damaged prior to deposition but that the teacups were complete, 
indicating that teacups and their associated saucers were sometimes treated as a single functional unit (drawings by Vicki Herring, photographs by Dave Webb \& Craig Cessford).

FIG. 14

Materialised temporality of assemblage from Cellar 4 at the Grand Arcade site, Cambridge, deposited as backfilling in redundant feature 1843-45 after the death of Sarah Hopkins. The graph illustrates the date of selected material from the assemblage and compares it to the lifespan of the cellar where it was deposited, various individuals associated with the assemblage etc. The illustrated Chinese export porcelain plates of $c .1730-60$ (with the earliest dating to $c$. 1730-40) represent the oldest material present, whilst the black transferprinted tea bowls of 1828 or later are the most recent (photographs by Dave Webb).

FIG. 15

An assemblage deposited 1790-1810 in the Barnwell suburb of Cambridge contained seven creamware plates and two sauceboats plus lids with shell-edged underglaze green decoration. These have Rococo-inspired asymmetrical, undulating scalloped rims with impressed curved lines fashionable c. 1775-1800 and produced until c. 1810 (Hunter \& Miller 1994). Josiah Wedgwood was the earliest documented Staffordshire potter to use shell-edge motifs, introducing it in the mid-1770s and four of the plates bear the Wedgwood mark, although intriguingly the relatively uneven and arced nature of the mark is usually dated to $c$. 1759-69 when Wedgwood used printers' movable type rather than a single slug. One of the plates and one of the sauceboats are marked with the initial ' $\mathrm{IH}$ ', suggesting that they were made by John Harrison of Stoke who is listed in directories of 1781-83 (Pomfret 2008). This suggests that the service was purchased over time; beginning with the Wedgwood vessels in the 1770s, then shifting to Harrison when the shell-edge motif was rapidly adopted by many other 
English potteries in the 1780s before being deposited after the material became unfashionable c. 1800-10. Apart from the marks the ceramics were effectively indistinguishable, but they represented very different socio-economic entities when purchased.

FIG. 16

Percentages of main meat types from selected assemblages at the Grand Arcade site in Cambridge 1800-50, showing the variability of consumption at a crude level. The photographs of large mammal probably cattle bone from rump steak cut and sawn cattle pelvis from silverside/topside meat cut deposited as backfilling in redundant feature Sawpit 1 (1874-81) indicate that these were processed and purchased from professional butchers, who would have dismembered carcasses into clearly defined and widely recognised joints and then sold them to customers in smaller units (photographs by Lorrain Higbee). 


\section{LIST OF TABLE CAPTIONS}

\section{TABLE 1}

Minimum numbers of items in assemblages from the Grand Arcade site in broad chronological order, including both classic ‘clearance' groups and smaller assemblages. NS animal bone not studied, fragment count in brackets. * - total count where animal bone has not been studied. Some features occur more than once, this is when there are two temporally distinct assemblages within a single feature.

\section{TABLE 2}

Grand Arcade site, 1760-1940, and numbers of selected feature types and the occurrence of large and small assemblages in them, demonstrating that large assemblages are only present in a minority of any type of feature and that their prevalence varied considerably between different types of feature.

\section{TABLE 3}

Material deposited in different types of feature in a garden associated with a school that operated at the Grand Arcade site $c$. 1820-66, by MNI. This demonstrates that the prevalence of types of material varied according to the type of deposit and indicates that they are complimentary with a consideration of all deposit types providing a more comprehensive albeit still incomplete view of the material culture associated with the school.

\section{TABLE 4}

Faunal remains from large assemblages at the Grand Arcade site with more than ten animal bones present, deposited 1800-50. Quantification by MNBU and EMW (Estimated Meat 
Weight, in $\mathrm{kg}$ ) for the principal species allows the relative quantities of meat consumed to be compared. Infrequent and potentially non-food bird species (teal/garney, grey plover, small wader, grey heron, herring gull and swan) not included. 
Throwing away everything but the kitchen sink? Large assemblages, depositional practice and post-medieval households in Cambridge

By CRAIG CESSFORD

\section{SUMMARY IN FRENCH, GERMAN, ITALIAN AND SPANISH}

\section{RÉSUMÉ \\ Mettre le paquet : grands assemblages, pratique de dépôt et foyers postmédiévaux à Cambridge}

Les archéologues financés par les entrepreneurs qui ont fouillé des sites postérieurs à 1750 en Grande-Bretagne ont fréquemment mis au jour de grands assemblages de matériel, qui semblent avoir été rapidement déposés en signes distinctifs par des maisons de particuliers et autres groupes. De tels assemblages possèdent un potentiel interprétatif considérable, mais cela reste encore à exploiter pleinement. Cet article propose une approche nuancée à l'analyse de tels assemblages, qui est très attentive au séquençage stratigraphique et aux facteurs de dépôt historiques.

\section{ZUSAMMENFASSUNG}

Alles wegwerfen außer der Küchenspüle?: Große Ansammlungen, Wegwerfpraktik und nach-mittelalterliche Haushalte in Cambridge

Von Bauunternehmern finanzierte Archäologen untersuchten Stätten nach 1750 in Britannien und fanden oft große Ansammlungen von Material, das scheinbar sehr schnell in Gruben gelagert, hauptsächlich aus Artikeln besonderer Haushalte oder anderen Fundgruppen bestand. Diese Ansammlungen enthalten erhebliche interpretative Möglichkeiten, aber dies muß erst voll ausgewertet werden. Dieser Artikel schlägt eine nuancierte Annäherung für die Analyse so einer Ansammlung vor, eine die kritisch Faktoren wie stratigraphische Sequenzen und historische Ablagen-Gesichtspunkte mit einbezieht.

\section{RIASSUNTO}

Gettare tutto tranne l'acquaio della cucina? Depositi di grande consistenza e accumulo di materiali di scarto in contesti domestici post-medievali a Cambridge

Gli scavi finanziati dalle imprese costruttive e che hanno indagato in Gran Bretagna siti posteriori al 1750, hanno rinvenuto grandi quantità di materiale che sembra essersi depositato rapidamente, e che mostra caratteristiche riconducibili a specifici nuclei domestici o ad altri gruppi. Si tratta di depositi con un elevato potenziale interpretativo, che tuttavia non è stato ancora esplorato in maniera esaustiva. Questo lavoro propone un approccio non rigido all'analisi di tali depositi, tenendo sempre presente la sequenza stratigrafica e i fattori storici che hanno portato alla loro formazione. 
¿Tirando todo menos el fregadero de la cocina ? Grandes conjuntos, prácticas de deposición y casas post-medievales en Cambridge

Los arqueólogos que investigan solares posteriores a 1750 en Gran Bretaña suelen encontrarse por lo general grandes cantidades de material que parece haber sido desechado rápidamente por determinadas familias u otros grupos. Estos conjuntos de material tienen un gran potencial interpretativo, pero uno que no se han aprovechado plenamente todavía. Este artículo propone un enfoque matizado para el análisis de tales conjuntos, uno que tiene en cuenta las secuencias estratigráficas y otros factores que influyeran en estos desechos históricos. 


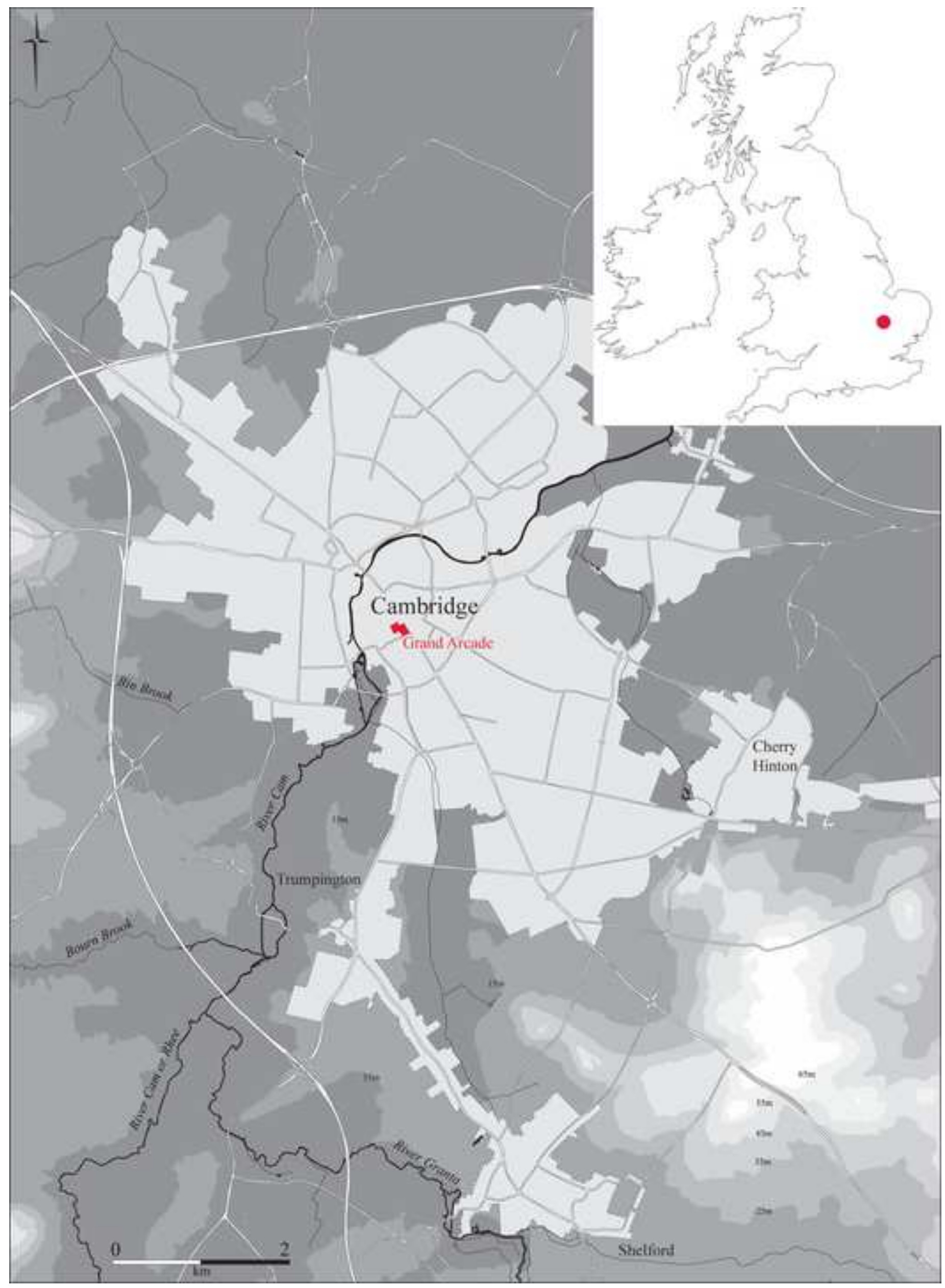




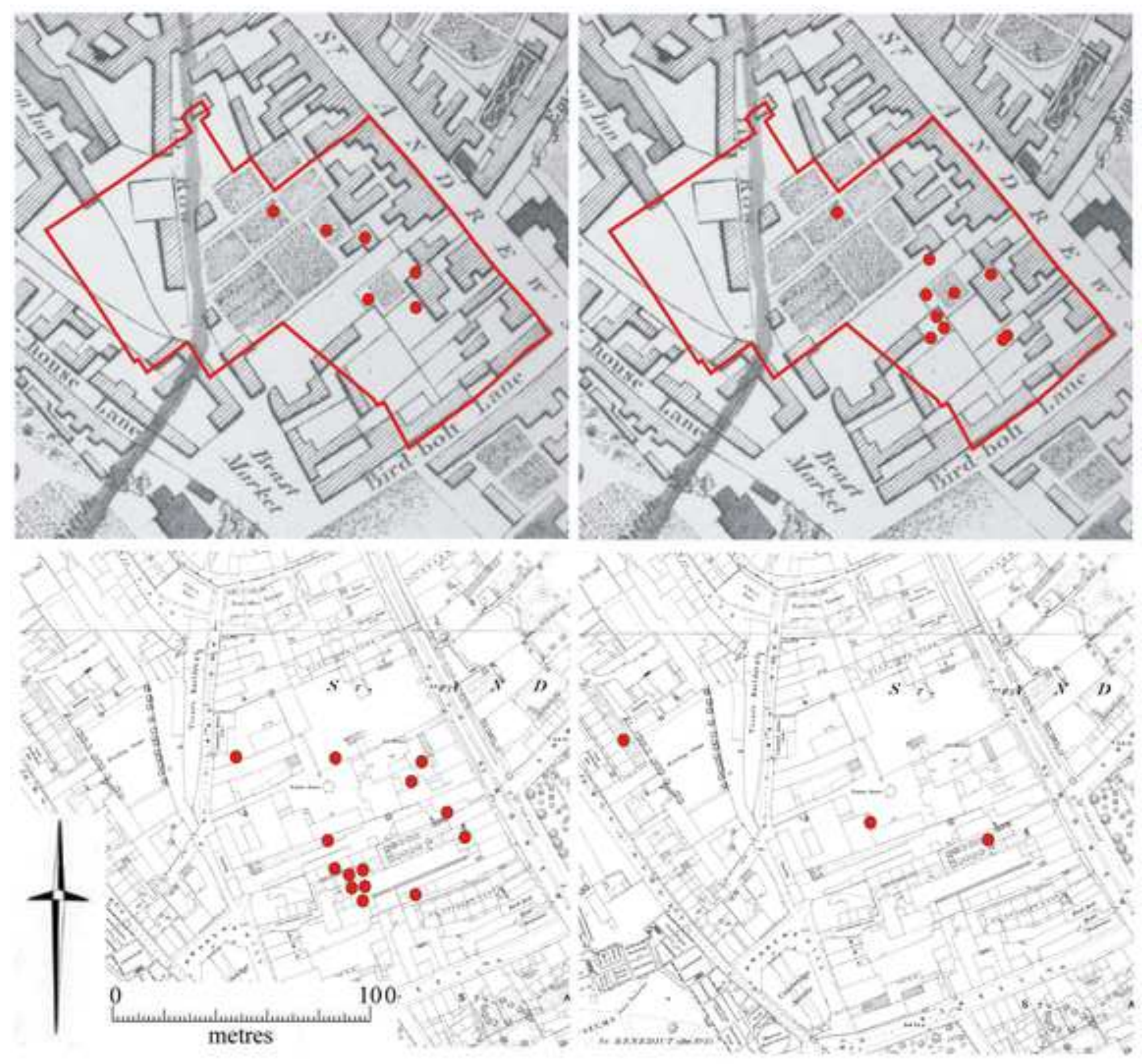



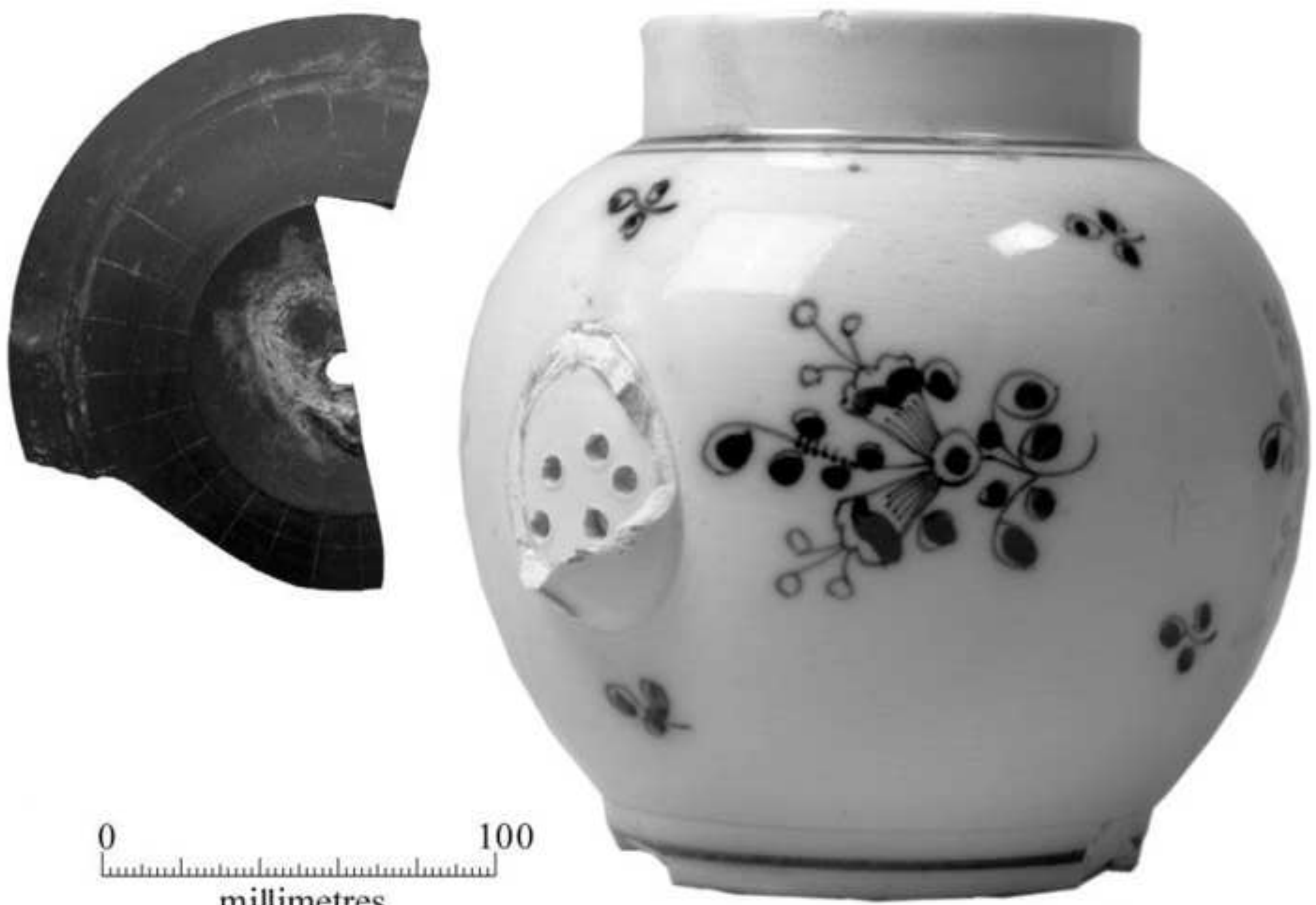
millimetres 

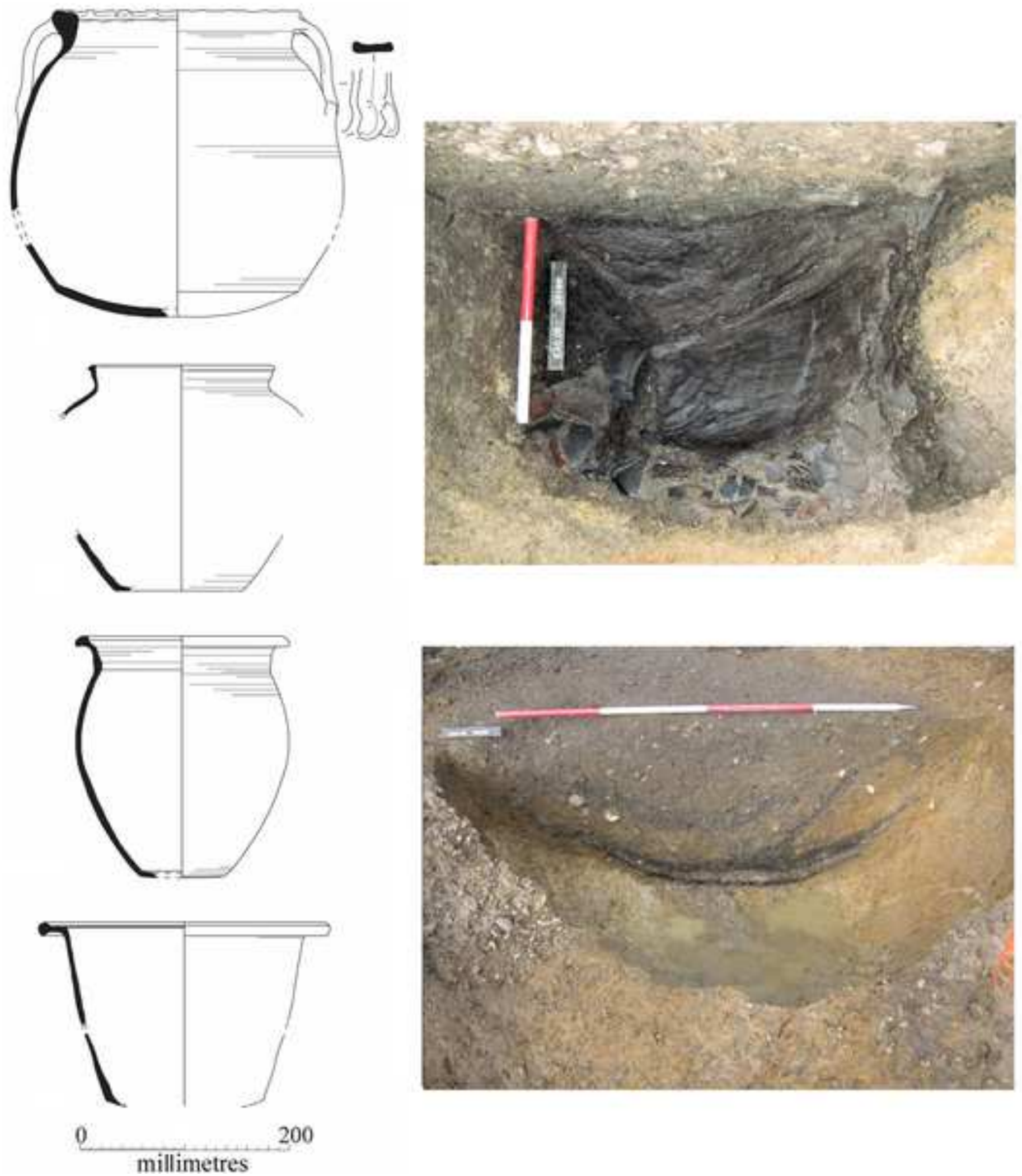

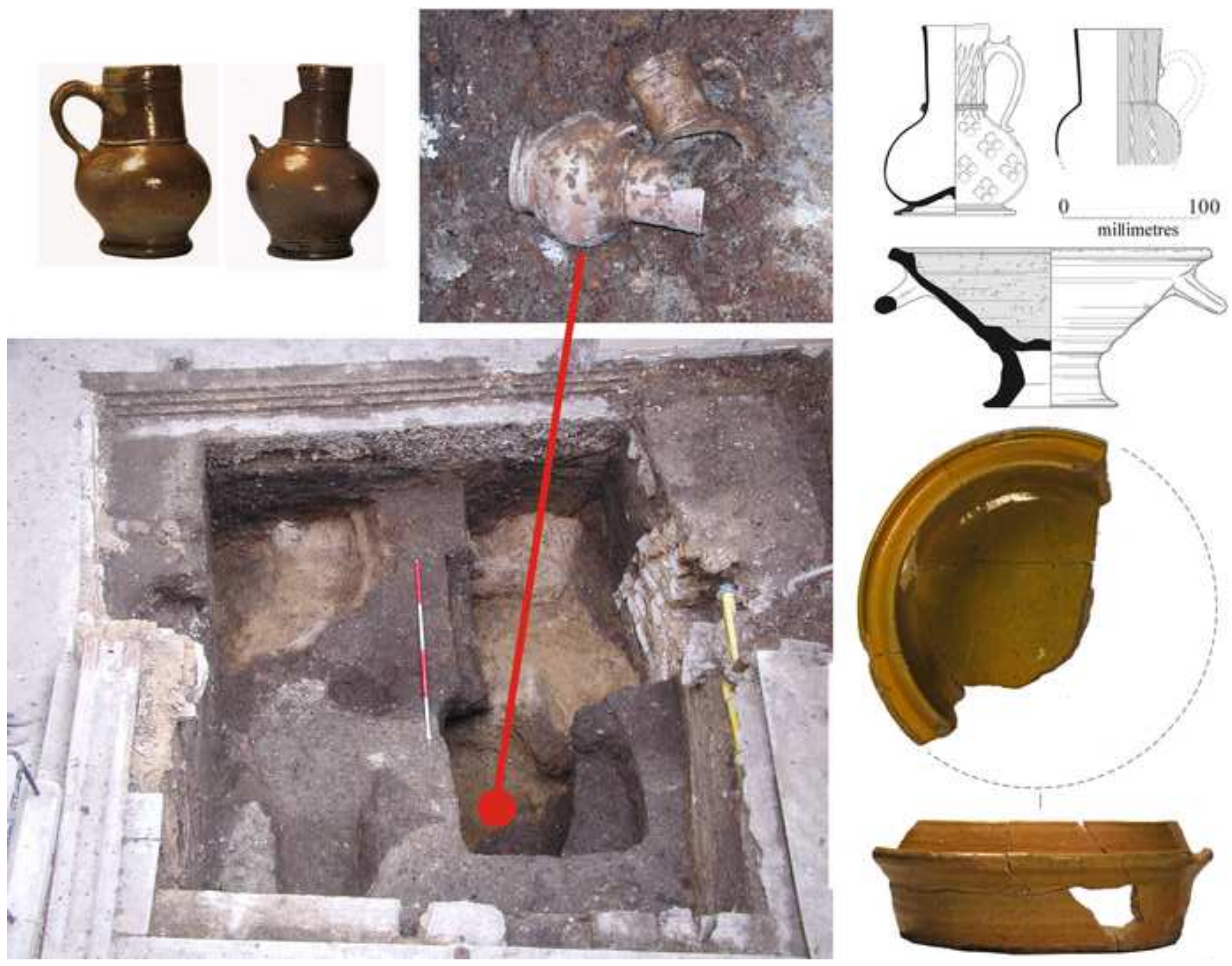

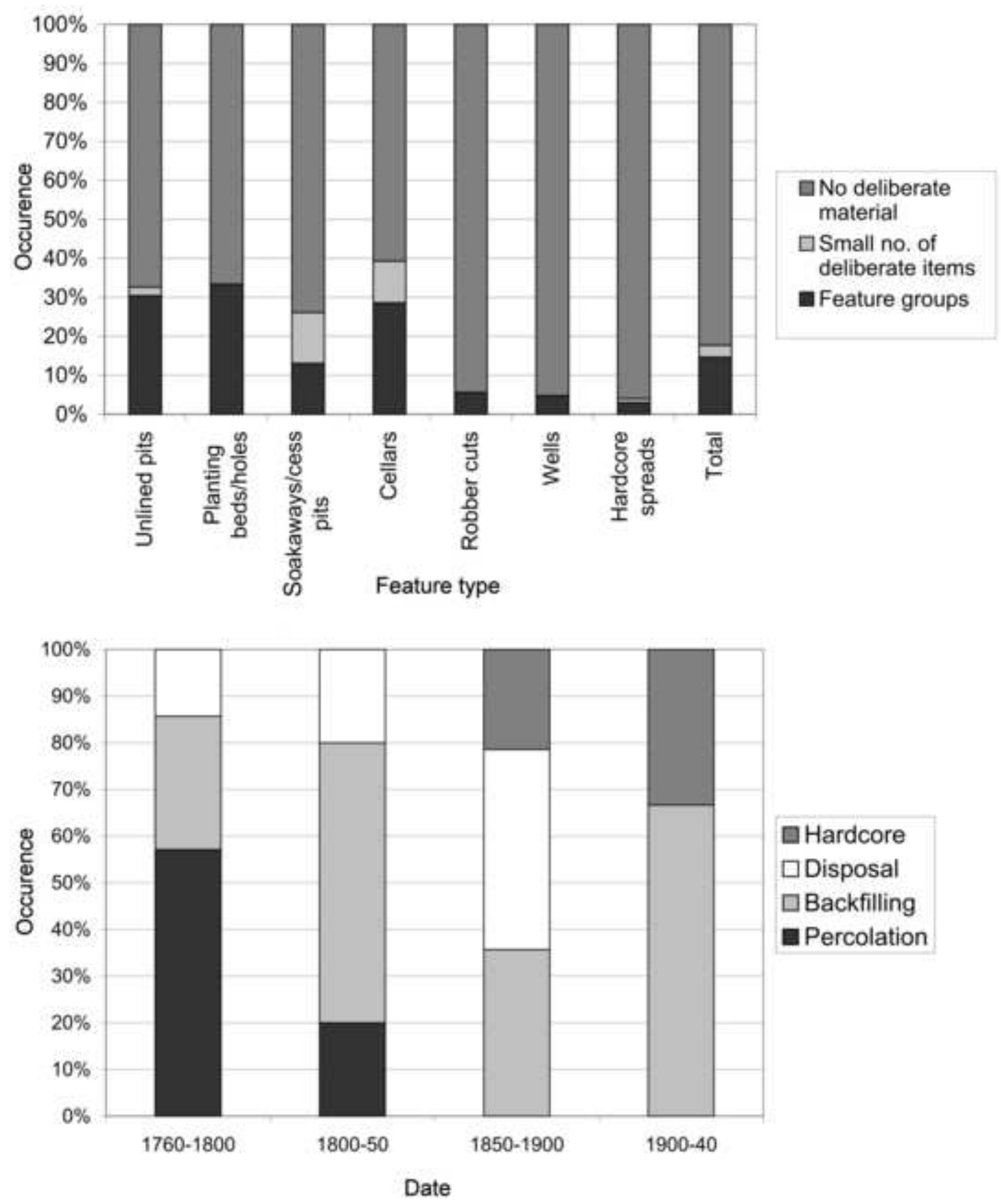

№ deliberate material

$\square$ Small no. of deliberate items

- Feature groups 

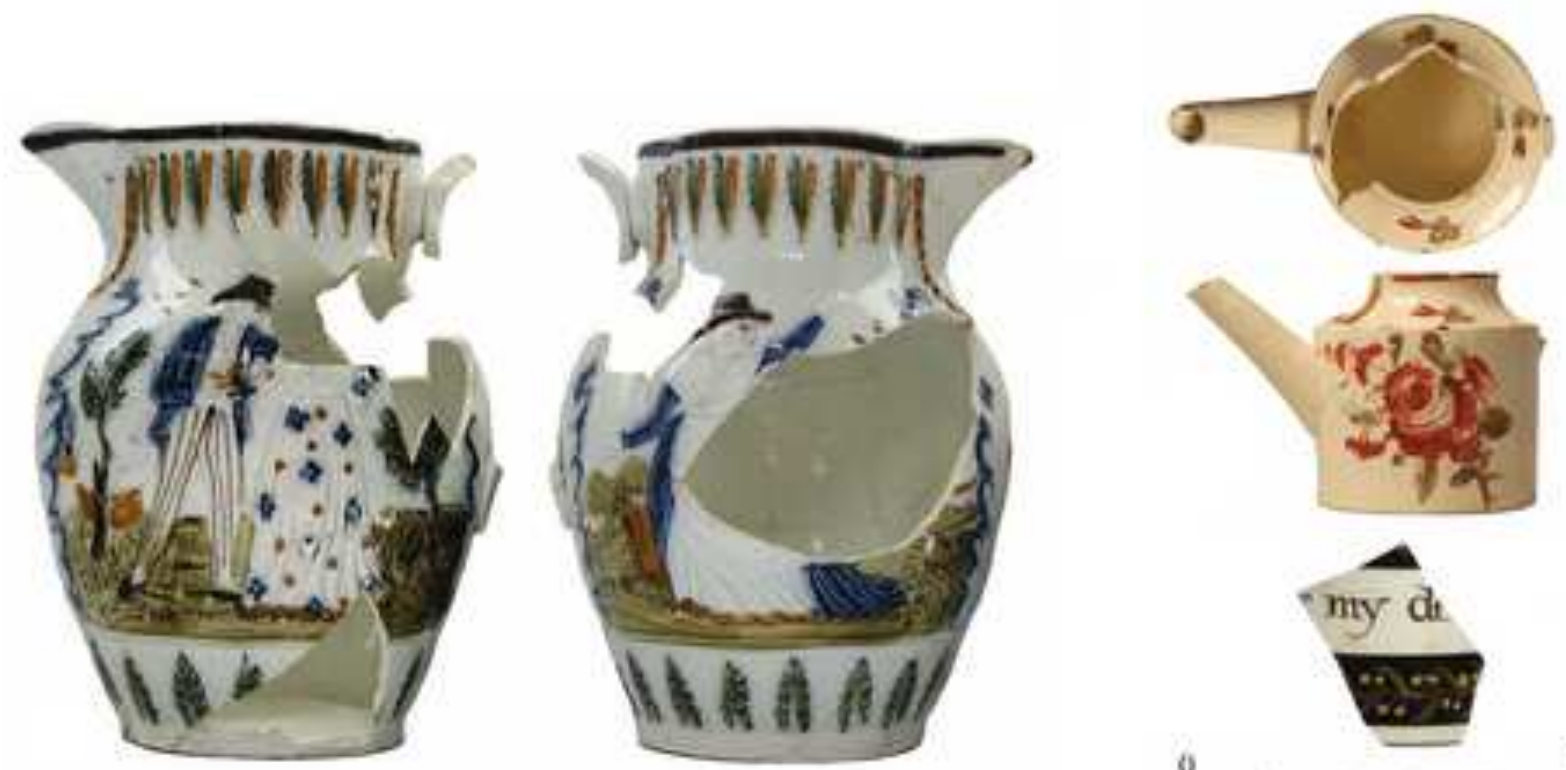

0

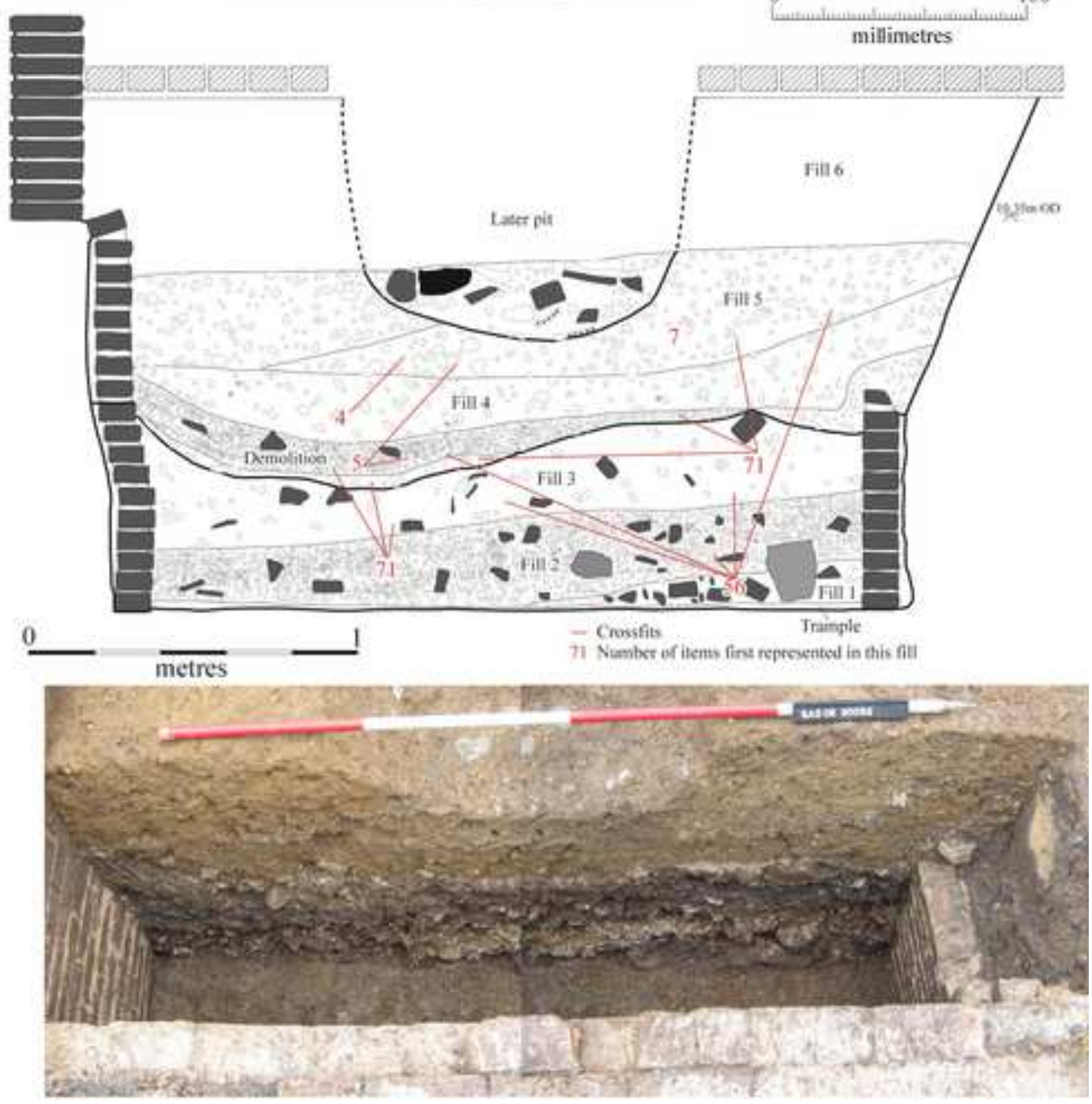




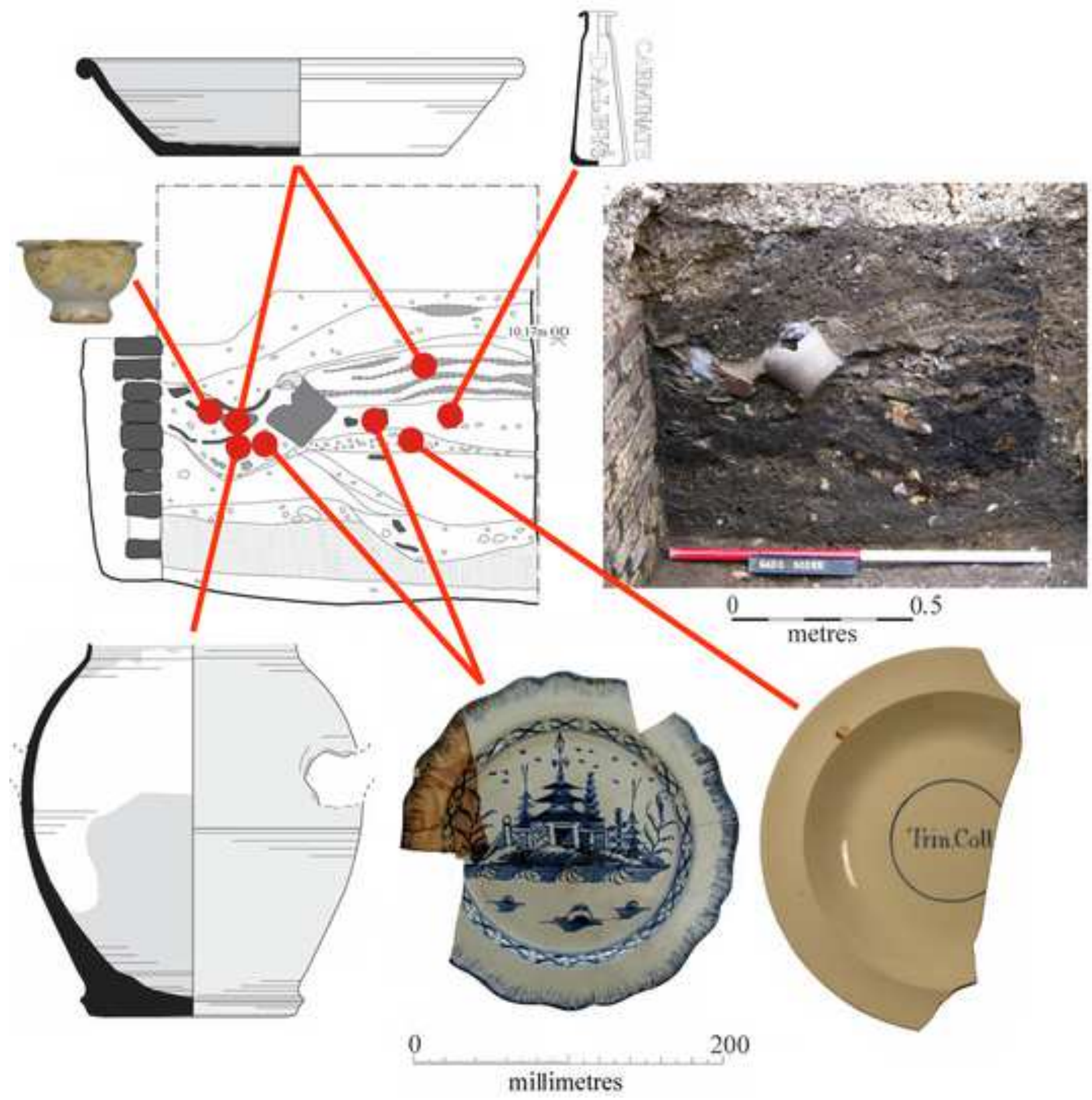


Click here to download Colour figure Cessford 09 mod.jpg $\underline{\underline{ \pm}}$

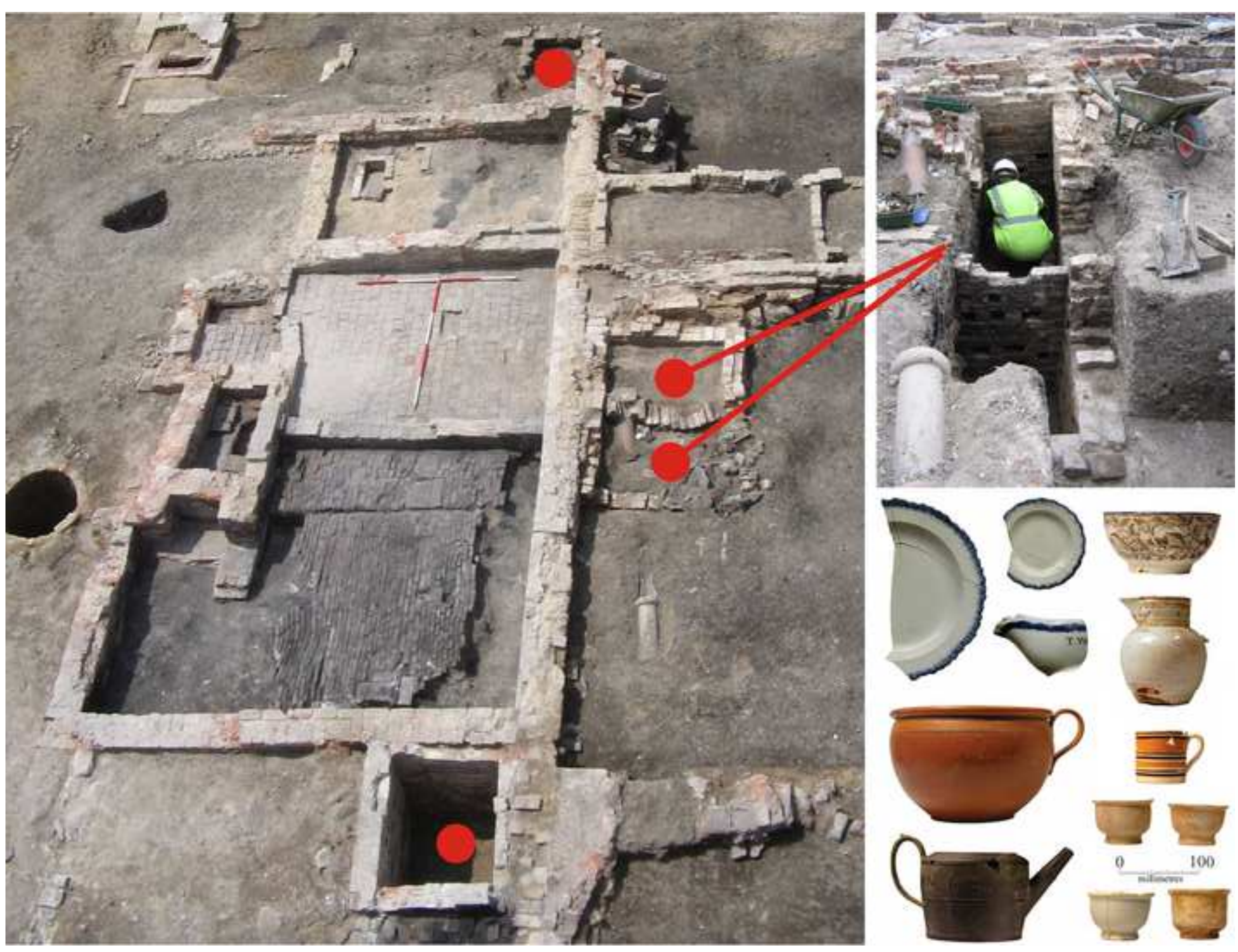



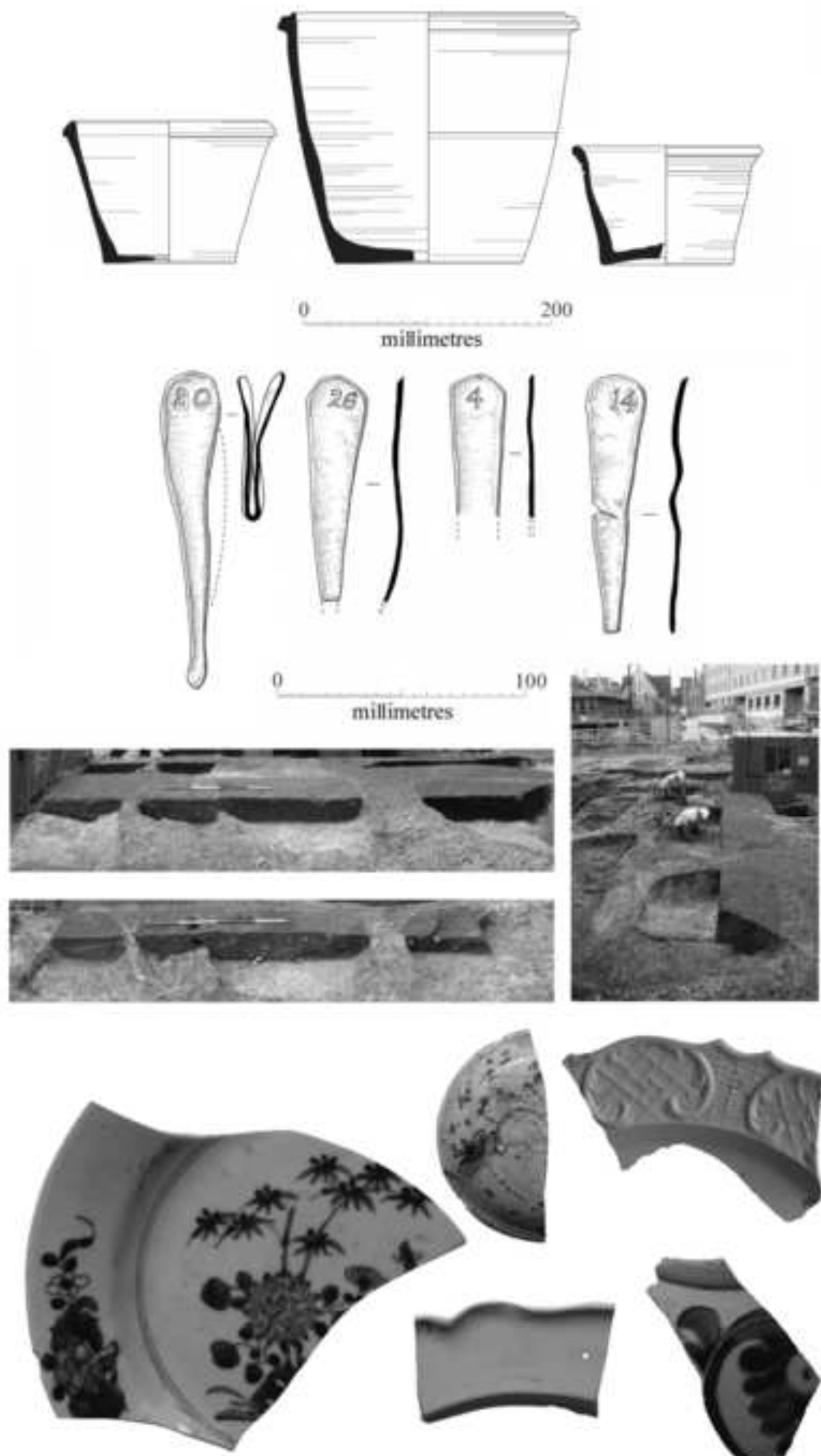

0 100

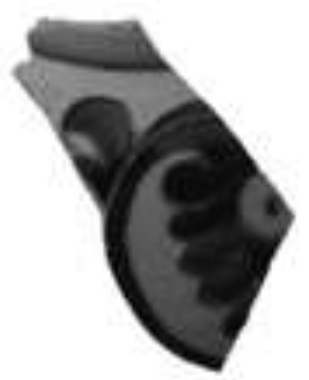
millimetres 

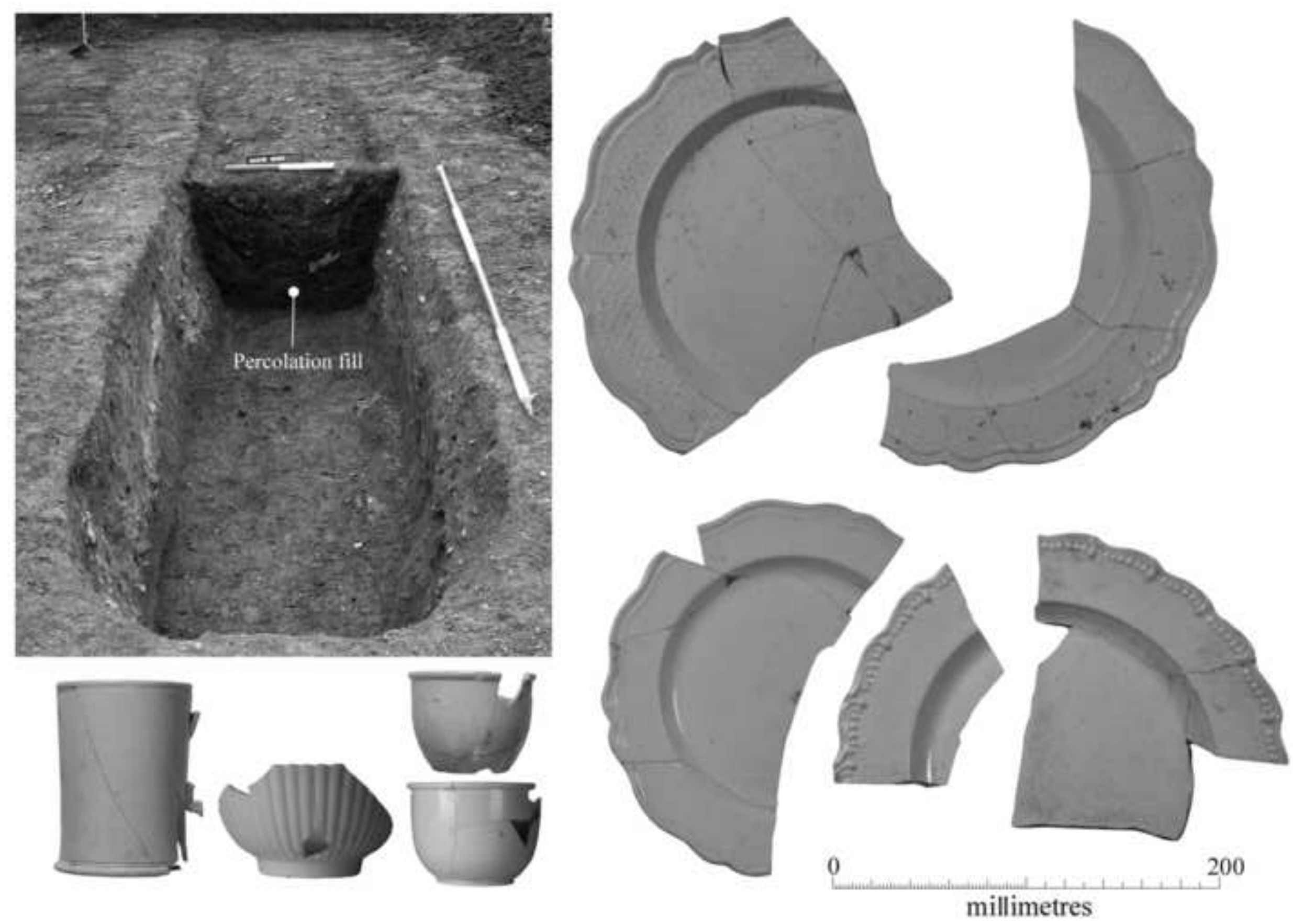


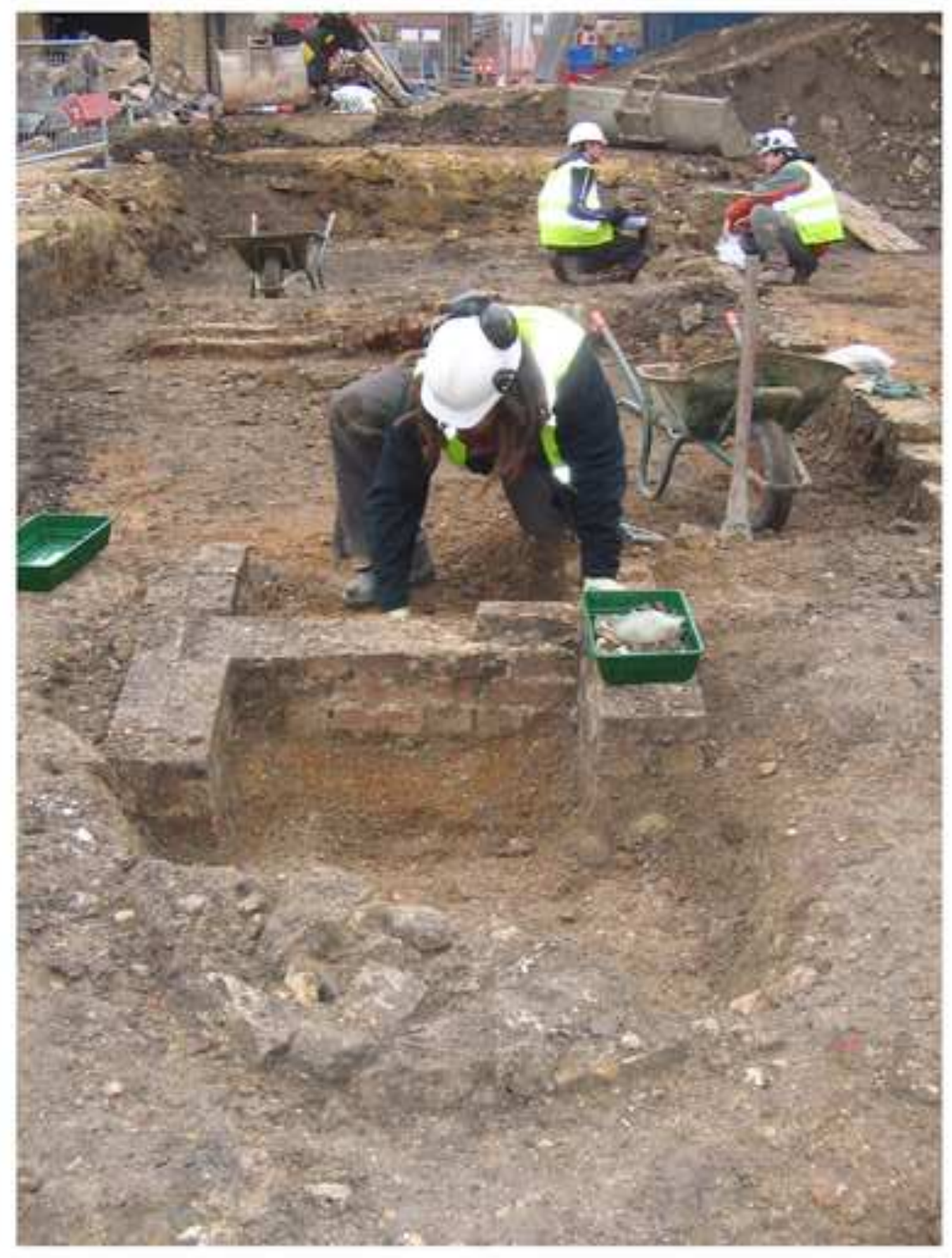

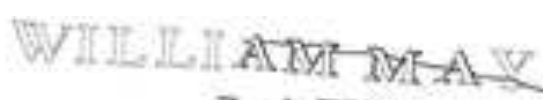
ILATE

DIS GRUCHY \& MI A Y O'S

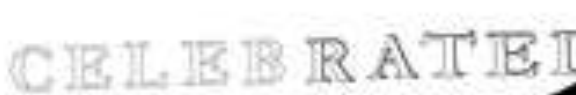

S(1) ATAIER.

17 SILVBX STPRESE,

I.ONIDQN.

BSTABIISIIBID 1809.

Gencin e Supprion

ASERATEDATERS

Sambridas

0

100

millimetres 

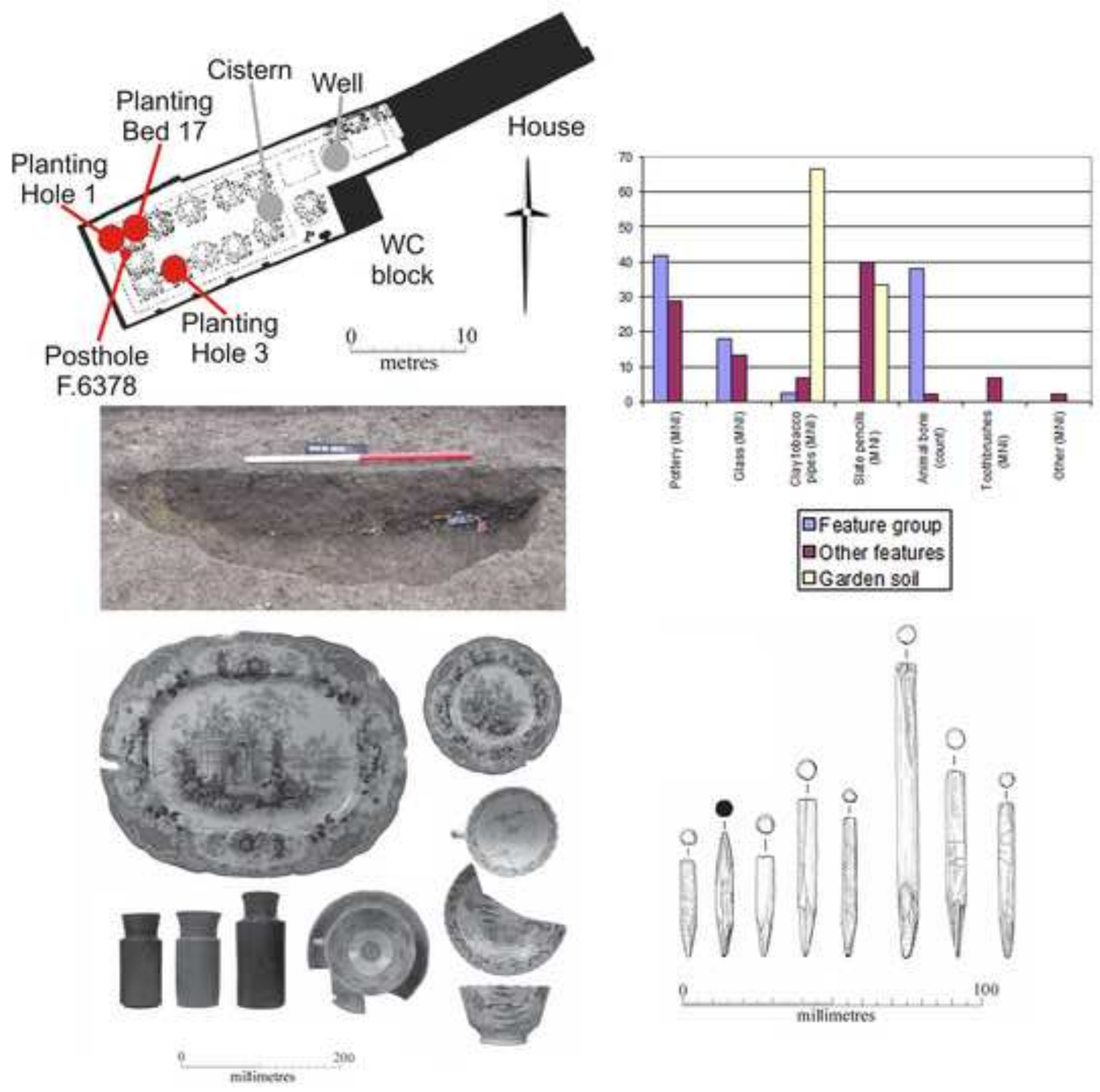


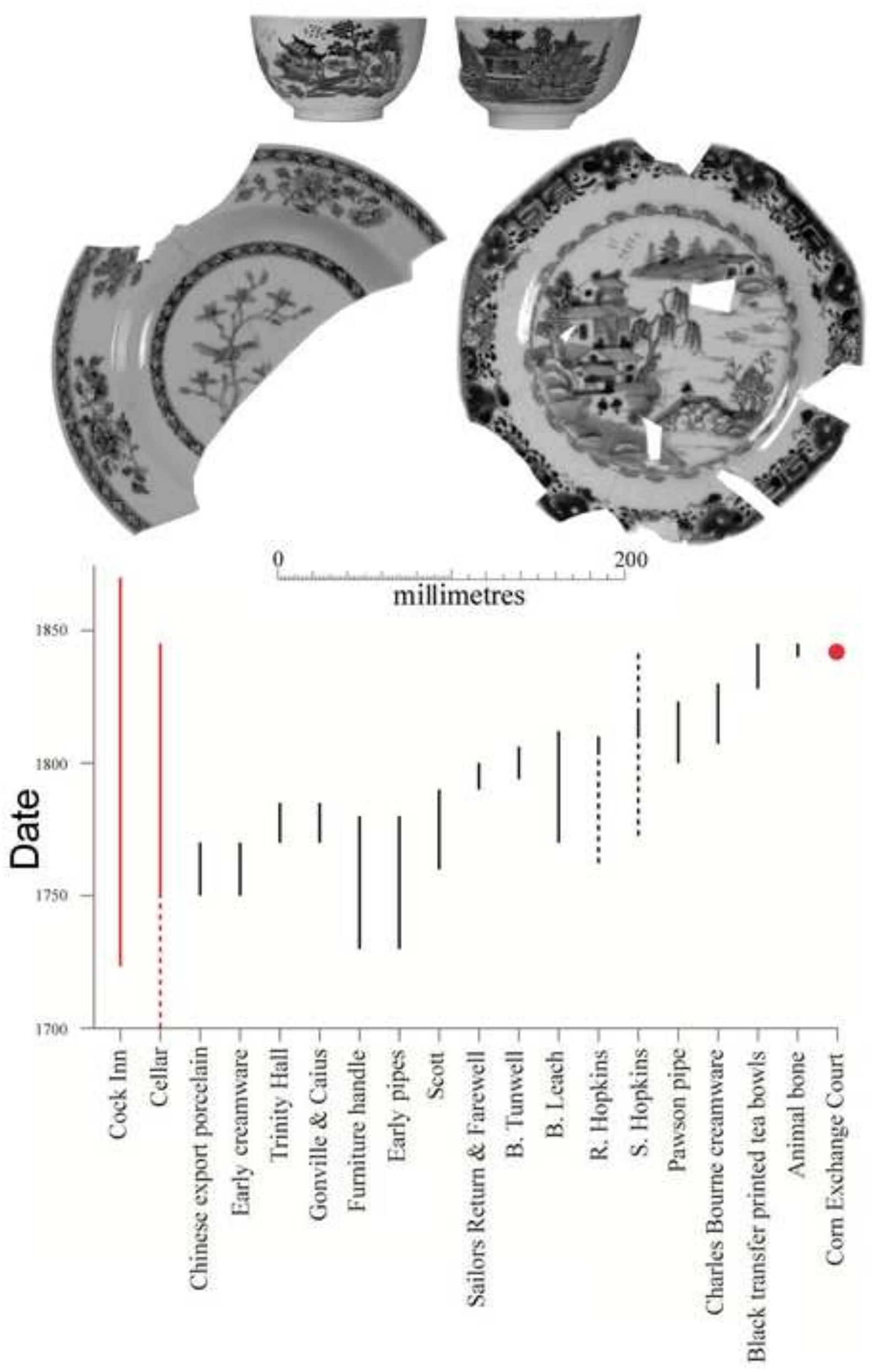


Click here to download Colour figure Cessford 15 mod.JPG $\underline{\underline{\Perp}}$
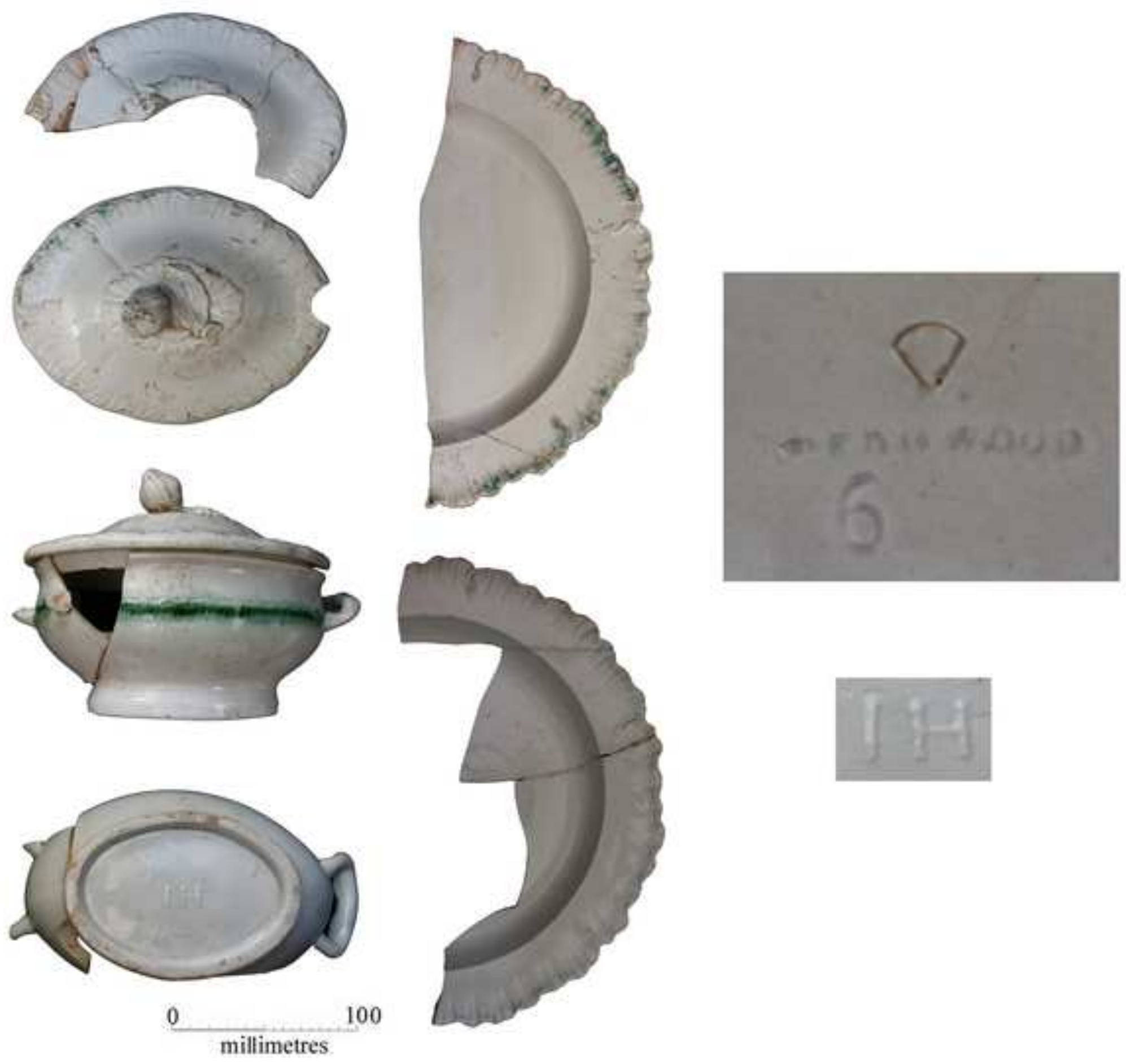

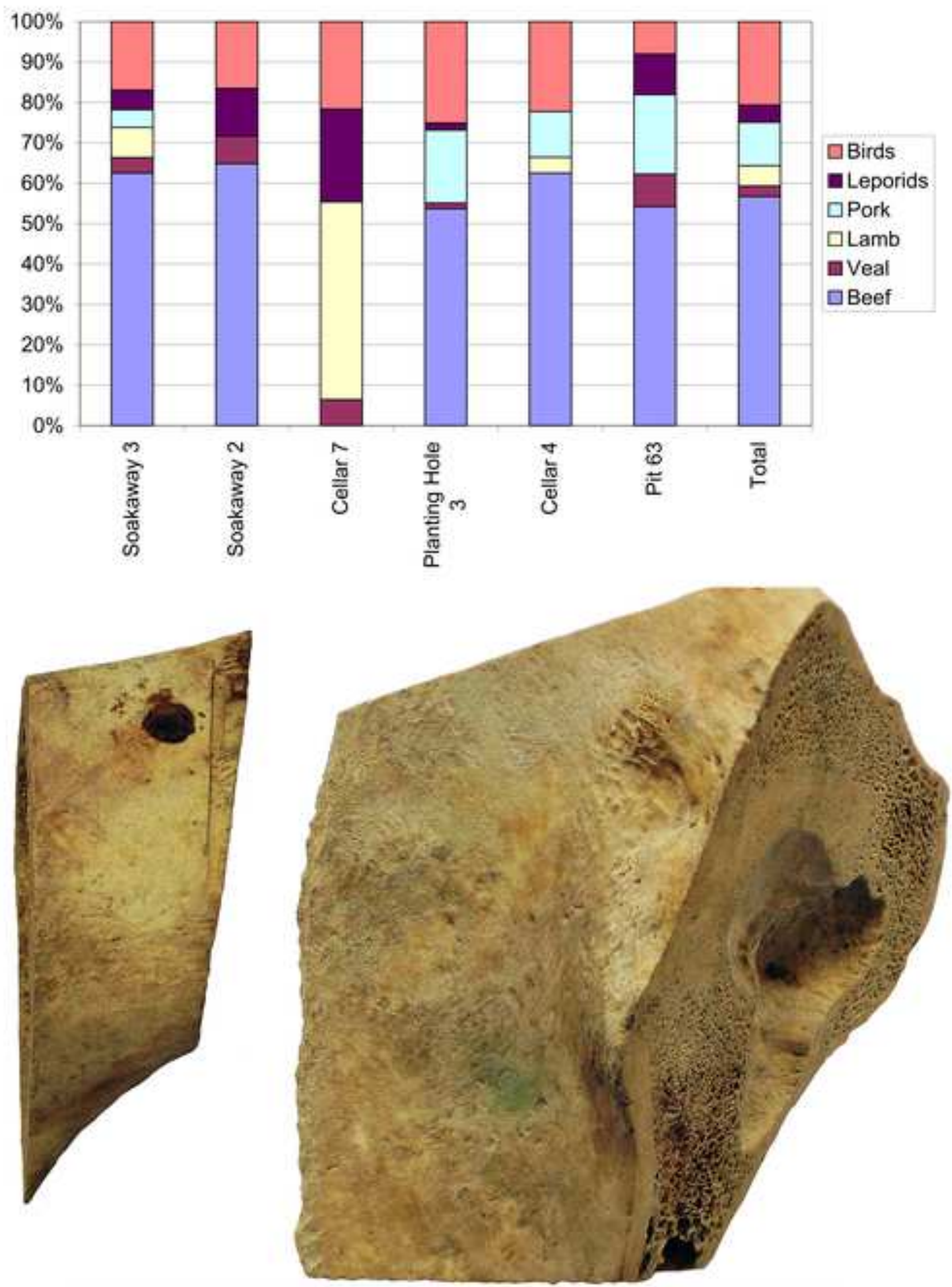

0

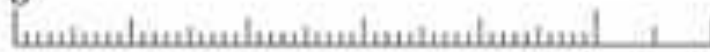




Feature Date Pottery Glass vessels Clay pipes Animal bone $\quad$ Other Total

\begin{tabular}{|c|c|c|c|c|c|c|c|}
\hline Planting bed 10 (percolation) & $1760-80$ & 27 & 0 & 1 & 24 & 0 & 52 \\
\hline Planting bed 9 (percolation) & $1760-80$ & 11 & 34 & 6 & NS (52) & 8 & $59 *$ \\
\hline Pit 57 (disposal) & $1760-80$ & 18 & 0 & 1 & 0 & 0 & 19 \\
\hline Planting beds $7-8$ (percolation) & $1770-90$ & 75 & 10 & 8 & NS (246) & 3 & $96^{*}$ \\
\hline Planting bed 11 (percolation) & $1770-90$ & 34 & 5 & 2 & 18 & 3 & 62 \\
\hline Soakaway 4 (backfilling) & $1780-90$ & 11 & 2 & 0 & NS (6) & 0 & $13 *$ \\
\hline Cellar 6 (backfilling) & $1780-90$ & 76 & 12 & 1 & 30 & 4 & 123 \\
\hline Sub-total & $1760-1800$ & 252 & 63 & 19 & - & 18 & $417 *$ \\
\hline Planting beds $7-8$ (disposal) & $1800-20$ & 100 & 0 & 0 & NS (246) & 9 & $109^{*}$ \\
\hline Soakaway 3 (backfilling) & $1808-25$ & 177 & 69 & 17 & 34 & 4 & 301 \\
\hline Soakaway 2 (backfilling) & $1813-23$ & 68 & 23 & 4 & 21 & 3 & 119 \\
\hline Cellar 7 (backfilling) & $1820-30$ & 52 & 7 & 1 & 18 & 0 & 78 \\
\hline
\end{tabular}




\begin{tabular}{|c|c|c|c|c|c|c|c|}
\hline Planting hole 3 (percolation) & $1828-34$ & 54 & 23 & 3 & 49 & 0 & 129 \\
\hline Cellar 7 (backfilling) & $1830-50$ & 35 & 1 & 12 & NS (83) & 1 & $49^{*}$ \\
\hline Planting hole 1 etc. (percolation) & $1832-45$ & 9 & 4 & 1 & NS (7) & 3 & $17^{*}$ \\
\hline Cellar 4 (backfilling) & $1843-45$ & 205 & 13 & 10 & 51 & 11 & 290 \\
\hline Pit 63 (backfilling) & $1843-45$ & 69 & 10 & 6 & 11 & 1 & 97 \\
\hline Pit 64 (disposal) & $1843-45$ & 28 & 2 & 1 & NS (95) & 0 & $31^{*}$ \\
\hline Sub-total & $1800-50$ & 797 & 152 & 55 & - & 32 & 1036 \\
\hline Pit 68 (disposal) & $1828-80$ & 35 & 2 & 1 & 0 & 1 & 39 \\
\hline Well 37 (backfilling) & $1840-60$ & 87 & 41 & 1 & NS (65) & 10 & $139 *$ \\
\hline Foundation 1 (hardcore) & $1862-1900$ & 12 & 0 & 0 & 0 & 0 & 12 \\
\hline Pit 60 (disposal) & $1866-69$ & 0 & 20 & 0 & 0 & 0 & 20 \\
\hline Cellar 5 (backfilling) & $1870-80$ & 19 & 0 & 1 & 0 & 0 & 20 \\
\hline Pit 62 (disposal) & $1873-1900$ & 12 & 2 & 1 & 0 & 0 & 15 \\
\hline Sawpit 1 (backfilling) & $1874-81$ & 33 & 30 & 1 & NS (56) & 12 & $76^{*}$ \\
\hline Building 49 (backfilling) & 1879-82 & 236 & 11 & 0 & NS (5) & 2 & $249 *$ \\
\hline Pit 65 (disposal) & 1880-1900 & 7 & 39 & 0 & 0 & 49 & 95 \\
\hline Pit 67 (disposal) & $1881-1900$ & 69 & 20 & 1 & NS (2) & 3 & $93 *$ \\
\hline
\end{tabular}




\begin{tabular}{|c|c|c|c|c|c|c|c|}
\hline Cellar 12 (backfilling) & $1882-85$ & 178 & 122 & 5 & NS (22) & 5 & $310^{*}$ \\
\hline Building 51 (hardcore) & 1882-1900 & 174 & 10 & 0 & 0 & 3 & 187 \\
\hline Foundation 3 (hardcore) & 1884-90 & 1 & 154 & 1 & NS (39) & 0 & $156^{*}$ \\
\hline Pit 61 (disposal) & $1884-90$ & 4 & 27 & 0 & 0 & 0 & 31 \\
\hline Sub-total & $1850-1900$ & 867 & 478 & 12 & - & 85 & 1442 \\
\hline Cellar 11 (backfilling) & $1912-21$ & 31 & 4 & 0 & 0 & 2 & 37 \\
\hline Cellar 13 (backfilling) & $1913-21$ & 500 & 160 & 1 & NS (9) & 25 & $686^{*}$ \\
\hline Foundation 4 (hardcore) & $1924-40$ & 157 & 8 & 0 & 0 & 1 & 166 \\
\hline Sub-total & $1900-40$ & 688 & 172 & 1 & - & 28 & 889 \\
\hline Total & $1760-1940$ & 2604 & 865 & 87 & - & 163 & 3719 \\
\hline
\end{tabular}




\begin{tabular}{|c|c|c|c|c|c|}
\hline Feature type & Function of material & $\begin{array}{c}\text { Large } \\
\text { assemblages }\end{array}$ & $\begin{array}{c}\text { Small } \\
\text { assemblages }\end{array}$ & $\begin{array}{l}\text { Total no. of } \\
\text { feature type }\end{array}$ & $\begin{array}{c}\text { \% of features } \\
\text { containing large } \\
\text { assemblages }\end{array}$ \\
\hline Unlined pits & None apparent & 14 & 1 & 46 & 23 \\
\hline Planting beds/holes & Percolation fill & 8 & 0 & 24 & 33 \\
\hline Soakaways/cess pits & Percolation fill or backfilling redundant feature & 3 & 3 & 23 & 13 \\
\hline Cellars & Backfilling redundant feature & 8 & 3 & 28 & 29 \\
\hline Robber cuts & Backfilling redundant feature & 1 & 0 & 18 & 6 \\
\hline Wells & Backfilling redundant feature & 1 & 0 & 21 & 5 \\
\hline Hardcore spreads & Hardcore & 3 & 1 & c. 100 & 3 \\
\hline Total & & 38 & 8 & c. 260 & 14 \\
\hline
\end{tabular}




\begin{tabular}{|c|c|c|c|c|c|c|c|c|c|c|}
\hline Feature & Type of deposit & Date & Ceramic & Glass & $\begin{array}{c}\text { Clay tobacco } \\
\text { pipes }\end{array}$ & Slate pencils & Animal bone & Toothbrushes & Other & Total \\
\hline Planting Hole 3 & Large assemblage & $1828-34$ & 54 & 23 & 3 & 0 & 49 & 0 & 0 & 129 \\
\hline Planting Hole 1 & Small assemblage & $\begin{array}{l}\text { Early-mid } \\
\text { 19th century }\end{array}$ & 3 & 2 & 2 & 5 & 0 & 1 & 0 & 13 \\
\hline Posthole F.6378 & Small assemblage & $\begin{array}{l}\text { Early-mid } \\
\text { 19th century }\end{array}$ & 1 & 0 & 0 & 12 & 0 & 0 & 1 & 14 \\
\hline
\end{tabular}




\section{Total from}

small

assemblages

\begin{tabular}{lll}
\hline Garden soil test & Early-mid \\
pits & Fragments & 19th century
\end{tabular}

Early-mid

19th century 


\begin{tabular}{|c|c|c|c|c|c|c|c|c|c|c|c|c|c|}
\hline Meat & Joint & $\begin{array}{l}\text { Soakaway } \\
3 \text { MNBU }\end{array}$ & $\begin{array}{c}\text { Soakaway } \\
3 \text { EMW }\end{array}$ & $\begin{array}{l}\text { Soakaway } \\
2 \text { MNBU }\end{array}$ & $\begin{array}{c}\text { Soakaway } \\
2 \text { EMW }\end{array}$ & $\begin{array}{l}\text { Cellar } 7 \\
\text { MNBU }\end{array}$ & $\begin{array}{c}\text { Cellar } 7 \\
\text { EMW }\end{array}$ & $\begin{array}{c}\text { Planting } \\
\text { hole } 3 \\
\text { MNBU }\end{array}$ & $\begin{array}{c}\text { Planting } \\
\text { Hole } 3 \\
\text { EMW }\end{array}$ & $\begin{array}{l}\text { Cellar } 4 \\
\text { MNBU }\end{array}$ & $\begin{array}{c}\text { Cellar } 4 \\
\text { EMW }\end{array}$ & $\begin{array}{l}\text { Pit } 63 \\
\text { MNBU }\end{array}$ & $\begin{array}{l}\text { Pit } 63 \\
\text { EMW }\end{array}$ \\
\hline \multirow[t]{8}{*}{ Beef } & Leg & & & 1 & 6.5 & & & & & 5 & 32.5 & & \\
\hline & Thick flank & 3 & 27.9 & 4 & 9.3 & & & 1 & 9.3 & & & & \\
\hline & Neck and clod & 1 & 13.5 & & & & & 1 & 13.5 & 3 & 40.5 & 1 & 13.5 \\
\hline & ?Topside/silverside & & & & & & & 3 & 34.5 & & & & \\
\hline & ?Fore rib/fillet/sirloin & & & 1 & 11.7 & & & & & 1 & 9.95 & & \\
\hline & Shin & 1 & 4.1 & & & & & & & & & & \\
\hline & Chuck and blade & 1 & 19.7 & & & & & 1 & 19.7 & & & & \\
\hline & Total & 6 & 65.2 & 6 & 27.5 & $\mathbf{0}$ & $\mathbf{0}$ & 5 & 77.0 & 9 & 82.95 & 1 & 13.5 \\
\hline \multirow[t]{5}{*}{ Veal } & Neck and clod & & & 1 & 2.9 & & & & & & & & \\
\hline & Chuck and blade & 1 & 4.0 & & & & & & & & & & \\
\hline & Thick flank & & & & & & & 1 & 2.0 & & & 1 & 2.0 \\
\hline & Leg & & & & & 1 & 1.4 & & & & & & \\
\hline & Total & 1 & 4.0 & 1 & 2.9 & 1 & 1.4 & 1 & 2.0 & $\mathbf{0}$ & $\mathbf{0}$ & 2 & 2.0 \\
\hline \multirow[t]{5}{*}{ Mutton } & Leg & 3 & 9.9 & 5 & 16.5 & 1 & 3.3 & 10 & 33.0 & 5 & 16.5 & 2 & 6.6 \\
\hline & Shoulder & 2 & 8.6 & 4 & 4.3 & & & 2 & 8.6 & 6 & 34.4 & 1 & 4.3 \\
\hline & Scrag & 1 & 0.3 & & & & & & & & & & \\
\hline & ?Loin/chump & 1 & 1.3 & & & & & 1 & 1.3 & 1 & 1.3 & 1 & 1.3 \\
\hline & Total & 7 & 20.1 & 9 & 20.8 & 1 & 3.3 & 13 & 42.9 & 12 & 52.2 & 4 & 10.9 \\
\hline \multirow[t]{3}{*}{ Lamb } & Leg & & & & & 1 & 2.03 & & & & & & \\
\hline & Shoulder & 3 & 7.8 & & & 3 & 7.8 & & & 2 & 5.2 & & \\
\hline & ?Loin & & & & & 1 & 0.8 & & & & & & \\
\hline
\end{tabular}




\begin{tabular}{|c|c|c|c|c|c|c|c|c|c|c|c|c|c|}
\hline & Total & 3 & 7.8 & 0 & 0 & 5 & 10.63 & 0 & 0 & 2 & 5.2 & 0 & 0 \\
\hline \multirow[t]{4}{*}{ Pork } & Head & & & & & & & & & & & 1 & 2 \\
\hline & Shoulder/hand & & & & & & & 1 & 2.9 & 2 & 5.8 & 1 & 2.9 \\
\hline & Leg & 1 & 4.6 & & & & & 5 & 23 & 2 & 9.2 & & \\
\hline & Total & 1 & 4.6 & $\mathbf{0}$ & $\mathbf{0}$ & $\mathbf{0}$ & $\mathbf{0}$ & 6 & 25.9 & 4 & 15.0 & 2 & 4.9 \\
\hline Hare & & 1 & 2.5 & 1 & 2.5 & 1 & 2.5 & & & & & 1 & 2.5 \\
\hline Rabbit & & 1 & 2.5 & 1 & 2.5 & 1 & 2.5 & 1 & 2.5 & & & 1 & 2.5 \\
\hline Leporids & Total & 2 & 5.0 & 2 & 5.0 & 2 & 5.0 & 1 & 2.5 & $\mathbf{0}$ & $\mathbf{0}$ & 2 & 2.5 \\
\hline Chicken & & 3 & 6.0 & 1 & 2.0 & 1 & 2.0 & 12 & 24.0 & 7 & 14.0 & & \\
\hline Goose & & 1 & 3.0 & 1 & 3.0 & & & 1 & 3.0 & 1 & 3.0 & & \\
\hline Duck & & 1 & 2.0 & 1 & 2.0 & 1 & 2.0 & 3 & 6.0 & 6 & 12.0 & 1 & 2.0 \\
\hline Pigeon & & 3 & 1.5 & & & 1 & 0.5 & 2 & 1.0 & 1 & 0.5 & & \\
\hline Turkey & & 2 & 5.0 & & & & & & & & & & \\
\hline Grey & & & & & & & & & & & & & \\
\hline partridge & & 1 & 0.2 & & & 1 & 0.2 & 1 & 0.2 & & & & \\
\hline Red & & & & & & & & & & & & & \\
\hline & & & & & & & & 1 & 0.3 & & & & \\
\hline Pheasant & & & & & & & & 1 & 1.5 & & & & \\
\hline Bird & Total & 11 & 17.7 & 3 & 7 & 4 & 4.7 & 21 & 36 & 15 & 29.5 & 1 & 2 \\
\hline Total & & 31 & 124.4 & 21 & 63.2 & 13 & 25.03 & 48 & 187.3 & 42 & 184.85 & 12 & 37.7 \\
\hline
\end{tabular}




\section{Cessford response to reviewers comments}

In general I agreed with the reviewers comments and have addressed them

In a few cases that the reviewers raised this was not because of a genuine disagreement, but because I had been insufficiently clear. I have attempted to rectify this.

Some reviewers comments relate to the fact that I was talking about Cambridge specifically, rather than making statements that are nationally/internationally true. I have clarified this.

Having thought about it I have decided to try and sidestep the nomenclature issue of 'clearance' groups etc. somewhat. Whilst I feel it is important I didn't want to get too fixated upon it and it would have required a substantial lengthening of the discussion to do it justice. 